Federal Reserve Bank of Minneapolis

Research Department Staff Report 454

Revised July 2012

\title{
Transition to FDI Openness: Reconciling Theory and Evidence*
}

\author{
Ellen R. McGrattan
}

Federal Reserve Bank of Minneapolis

and University of Minnesota

\begin{abstract}
Empirical studies quantifying the economic effects of increased foreign direct investment (FDI) have not provided conclusive evidence that they are positive, as theory predicts. This paper shows that the lack of empirical evidence is consistent with theory if countries are in transition to FDI openness. Anticipated welfare gains lead to temporary declines in domestic investment and employment. Also, growth measures miss some intangible FDI, which is expensed from company profits. The reconciliation of theory and evidence is accomplished with a multicountry dynamic general equilibrium model parameterized with data from a sample of 104 countries during 1980-2005. Although no systematic benefits of FDI openness are found, the model demonstrates that the eventual gains in growth and welfare can be huge, especially for small countries.
\end{abstract}

Keywords: Foreign direct investment; Technology capital; Development JEL classcifiation: F21,F23,O32

\footnotetext{
* The research in this paper was presented in a plenary address at the annual meeting of the Society for Economic Dynamics in Montreal, July 2010. I thank my colleagues, four anonymous referees, and seminar participants at the London School of Economics, the European University Institute, Ohio State, Yale, the Cleveland Fed, the Bureau of Economic Analysis, Kansas State, and the NBER, for their comments on earlier drafts of the paper. For editorial assistance, I thank Kathy Rolfe and Joan Gieseke. For helpful tips on parallelizing my codes, I thank Graham Candler. Codes, data, and a separate technical appendix are available at my website, www.minneapolisfed.org/research. The views expressed herein are those of the author and not necessarily those of the Federal Reserve Bank of Minneapolis or the Federal Reserve System.
} 


\section{Introduction}

Theory predicts that the economic effects in a host country of increased foreign direct investment (FDI) are positive, but empirical studies have been unable to provide conclusive evidence consistent with that prediction. For example, Kose, Prasad, Rogoff, and Wei's (2009) survey of empirical cross-country studies reports that only one finds a positive impact of FDI on economic growth. ${ }^{1}$ Here, I show that these inconclusive findings do not contradict theory, but in fact are to be expected when countries are in transition to capital market openness.

I show this by closely examining such a transition period in a multicountry dynamic general equilibrium model developed in my 2010 work with Prescott. In the model, countries initially face restrictions on foreign capital investments, both FDI and portfolio, that are gradually relaxed. As restrictions on FDI are relaxed, foreign multinationals that have accumulated technology capital - know-how from investments in research and development (R\&D), brands, and organizations that are not specific to any one plant-have more opportunities to use this capital in subsidiaries abroad. As restrictions on portfolio investments are relaxed, households can borrow and lend to smooth out consumption over time. During the transition, I find that the model predicts per capita GDP and employment initially both fall below historical trends and do not recover until the restrictions are sufficiently relaxed.

GDP and employment decline for two reasons. One is that when such a relaxation is expected, households increase consumption and leisure in expectation of higher permanent income, thereby reducing domestic investment and labor. This income effect occurs because relaxed restrictions on future FDI imply a higher effective level of total factor productivity (TFP). The other reason for GDP declines is a measurement issue: firms make intangible investments that are expensed and thus not part of corporate profits. In the model, there

\footnotetext{
1 For more details, see their Table 3b.
} 
are two distinct types of intangible capital: technology capital that can be used in multiple locations and intangible capital that is plant specific. Theory predicts that plant-specific intangible investments made by the subsidiaries are abnormally high while barriers to FDI are being removed: that implies a negative correlation between FDI investment and host country GDP.

But, again, theory also predicts positive effects in the host country from increased FDI. GDP and employment eventually rise above trend once the transition period has passed. And, if there are no constraints on international borrowing and lending, consumption rises as soon as relaxed restrictions are announced. If there are borrowing constraints that limit portfolio investments, the rise in consumption is more gradual. But, in either case, welfare in the host country is higher.

I investigate the transition path to FDI openness in two versions of the model: a simple two-country version and a more realistically parameterized 104-country version.

The simple version of the model allows me to qualitatively describe, fairly precisely, the transition paths of various economic variables in countries of different sizes, where size is defined by population and level of technology. The transition is defined basically as the period between the time an announcement is made that FDI restrictions are to be relaxed at a specified future date and the time the restrictions are actually relaxed. I consider equilibrium paths with and without coincident restrictions on portfolio investments. The results obtained from the simple model provide some intuition for why empirical findings on the impact of FDI may be inconclusive.

The more realistic version allows me, first, to conduct the standard empirical analysis of quantifying the impact of FDI on economic growth. Countries are included in the analysis if they have complete data on inward FDI, net portfolio investment, GDP, and populations over the period 1980-2005. Observations on inward FDI are used to parameterize time paths of country openness parameters, which are policy parameters determining 
the inflow of FDI. Observations on net portfolio investment are used to parameterize borrowing constraints on portfolio flows. The model is simulated and growth in GDP per capita computed. The result of this 104-country analysis is consistent with that in the literature. Using standard analysis, the model finds no evidence of large positive effects from FDI. The amount of FDI in a country is not positively correlated with growth in GDP or TFP and not statistically significant in a standard cross-country growth recession.

Yet this same model does predict large positive effects to FDI openness, in terms of both growth and welfare. I demonstrate this effect by conducting a counterfactual experiment. I recompute equilibria for the 104-country version of the model, relaxing capital market restrictions almost completely for one country at a time, and estimate per capita growth in GDP and the welfare gain to each country from doing that. I find increases in annual growth rates in the range of 0 to 7 percentage points and welfare gains that are equivalent to consumption increases in the range of 4 percent to 460 percent. The gains in growth and welfare are both inversely related to country size.

A methodological contribution of my work here is the computation of equilibria in a dynamic general equilibrium model with a large number of integrated countries. Multinationals in the model choose investments in tangible capital, plant-specific intangible capital, and technology capital, both at home and abroad. With many countries and different types of capital, the problem is tractable only if the computations are divided across parallel processors. ${ }^{2}$ An initial guess for equilibrium prices and transfers is distributed across processors, and equilibrium quantities are computed and then passed back to the main processor. Prices and transfers are updated, and the algorithm continues until a fixed point is found.

The main findings of my analysis rely critically on the existence of intangible capital,

\footnotetext{
2 For example, in the 104-country version of the model, there are 21,736 different capital stocks.
} 
both technology capital accumulated by multinational parents and plant-specific intangible capital used by their foreign subsidiaries. There is a growing body of work concerned with the measurement of intangible capital. Estimates of investments in intangible capital by businesses are large, roughly the size of business investments in tangible capital. Many estimates are based in part on direct evidence of expenditures, for example, R\&D expenditures (National Science Foundation, 2012) and advertising expenditures (U.S. Department of Commerce, 2010). Investments in organization capital are not readily available, but alternative proxies have been proposed such as executive wages and management consulting fees (Corrado, Hulten, and Sichel, 2005), wages of creative workers (Nakamura, 2003), and sales, general, and administrative expenses (Lev and Radhakrishnan, 2005). There are also studies of organizational practices - such as greater use of teams, broader distribution of decision rights, and greater worker training - and their economic impact. For example, Brynjolfsson, Hitt, and Yang (2002) surveyed work practices of large firms and found that IT-intensive firms were more likely to adopt organizational practices and subsequent to adoption had higher market valuations and higher outputs than less IT-intensive firms. Comprehensive measures of intangible capital are found either by subtracting tangible capital stocks from corporate valuations (Hall, 2000) or by inferring magnitudes using neoclassical theory and data from national accounts and tax returns (McGrattan and Prescott, 2005). Whether the estimates are based on direct measures of (capitalized) expenditures or indirect measures from theory, the evidence suggests that intangible and tangible capital stocks in the business sector are of comparable magnitudes.

My work here is related to the literature that quantifies the impact of capital account liberalization. As noted above, cross-country studies have been unable to provide conclusive evidence about the positive impact of FDI on economic growth. If all capital account flows are considered, the results remain inconclusive. (See Kose et al. 2009, Table 3a.) The main positive effects of financial integration have been found for equity market liberalizations and in certain micro-level studies of FDI. However, according to Kose et 
al. (2009), the positive results for equity market liberalizations are still debatable "because it is so difficult to disentangle the effects of the bundled reforms that typically accompany equity liberalizations." (See their Table 3c.) In theory, the model used here can be used to study openness of portfolio equity flows, but the model predictions depend critically on what is assumed for the path of domestic TFP. The source of positive effects for the impact of FDI found in firm-level studies has been primarily through contacts between foreign affiliates and their local suppliers. (See, for example, Javorcik, 2004.) But, in a recent survey, Görg and Greenaway (2004) claim that empirical support for positive effects of FDI based on firm-level studies is "at best mixed." These mixed empirical results are the main motivation for my study.

Most of the theoretical work in the literature examining capital account liberalizations abstracts from FDI flows, focusing instead on portfolio investment and the integration of countries with different financial systems or levels of capital at different stages of financial development. ${ }^{3}$ Here, foreign direct and portfolio investment are both essential: lowering barriers to FDI increases the effective production sets for firms, and lowering barriers to portfolio investment allows households to better smooth consumption.

More directly relevant is the literature that uses economic theory to quantify the impact of FDI openness and finds large output and welfare gains. Burstein and MongeNaranjo (2009) estimate the gains of reallocating managerial know-how abroad using a span-of-control model as in Lucas (1978). Ramondo (2010) estimates the gains of lower barriers to FDI in a model without trade, but with multinational production. Ramondo and Rodríguez-Clare (2010, forthcoming) consider both trade and FDI in the same model. ${ }^{4}$ The results in these studies are the motivation for the current study, since they all conclude

3 Recent examples include Gourinchas and Jeanne (2006), Caballero, Farhi, and Gourinchas (2008), Mendoza, Quadrini, and Ríos-Rull (2009), and Aoki, Benigno, and Kiyotaki (2009).

4 In McGrattan and Prescott (2009), we concluded that there are large potential gains to FDI openness based on several numerical examples, but we did not calibrate the model to actual data. 
that the output and welfare gains to FDI openness are large, whereas empirical studies have found little conclusive evidence of positive economic effects. ${ }^{5}$

Section 2 lays out the multicountry general equilibrium model used in the analysis. Section 3 is a set of propositions that qualitatively characterize the transition path in a two-country version of the model. Section 4 is an application of the model to actual crosscountry data and therefore quantifies that transition path as well as the overall output and welfare gains. Section 5 concludes. Data sources and computational methods are discussed briefly in the appendices and in more detail in McGrattan (2012).

\section{Model}

In this section, I describe a multicountry general equilibrium model that builds on McGrattan and Prescott $(2009,2010)$. I describe first the problem solved by multinational companies and then the problems faced by households. Finally, I define a competitive equilibrium for the model economy and describe how to match up national accounting statistics with their model counterparts.

\subsection{Multinationals}

Multinational companies from country $j$ operating in country $i$ produce output $Y_{i t}^{j}$ in period $t$,

$$
Y_{i t}^{j}=A_{i t} \sigma_{i t}\left(N_{i t} M_{t}^{j}\right)^{\phi}\left(Z_{i t}^{j}\right)^{1-\phi}
$$

with technology capital $M_{t}^{j}$ and a composite of country-specific inputs denoted by $Z_{i t}^{j}{ }^{6}$ The parameter $\phi \geq 0$ governs technology capital's share of income. Technology capital is accumulated know-how from investments in such things as research and development

\footnotetext{
5 A recent empirical literature has begun to focus on countries that have passed certain thresholds when relaxing capital restrictions. See, for example, the work of Kose, Prasad, and Taylor (2011).

6 For a micro-foundation of this aggregate production function, see the work of McGrattan and Prescott (2009).
} 
$(R \& D)$, brands, and organizational capital that can be used in as many locations as firms choose, both at home and abroad. The total number of locations available in country $i$ in period $t$ is $N_{i t}$, and firms take this as given in solving their optimization problem. Since technology capital can be used simultaneously in multiple locations, it is not indexed by $i$. The span of control of this organizational capital is limited because countries are assumed to have a fixed number of production locations.

Country $i$ 's total factor productivity in $t$ is denoted by $A_{i t}$. For multinationals incorporated outside $i$, the effective level of productivity if they operate in $i$ is $A_{i} \sigma_{i}$, where $\sigma_{i}$ is the degree of openness of country $i$ to FDI. A value of 1 for $\sigma_{i}$ implies that the country is totally open - or that domestic and foreign firms have the same opportunities. A value of less than 1 implies that domestic and foreign firms are not treated equally by the host country. In particular, with $\sigma_{i}<1$, investment by foreign firms entails extra costs, and these costs have the same effect as if the foreign firms had lower TFP than domestic firms.

The composite capital-labor input in country $i$ is modeled as a Cobb-Douglas technology,

$$
Z_{i}^{j}=\left(K_{T, i}^{j}\right)^{\alpha_{T}}\left(K_{I, i}^{j}\right)^{\alpha_{I}}\left(L_{i}^{j}\right)^{1-\alpha_{T}-\alpha_{I}}
$$

with inputs of tangible capital $K_{T, i}^{j}$, plant-specific intangible capital $K_{I, i}^{j}$, and labor $L_{i}^{j}$. This specification of technology implies that multinationals use two types of intangible capital, one that is plant-specific and one that is not.

The stand-in multinational company from country $j$ maximizes the present value of the stream of after-tax dividends:

$$
\max \left(1-\tau_{d}\right) \sum_{t} p_{t} D_{t}^{j}
$$

where $\tau_{d}$ is the tax rate on dividends and the sum of dividends across all operations in all countries indexed by $i$ is given by $D_{t}^{j}=\sum_{i} D_{i t}^{j}$, with

$$
D_{i t}^{j}=\left(1-\tau_{p i}\right)\left(Y_{i t}^{j}-W_{i t} L_{i t}^{j}-\delta_{T} K_{T, i t}^{j}-X_{I, i t}^{j}-\chi_{i}^{j} X_{M, t}^{j}\right)-K_{T, i, t+1}^{j}+K_{T, i t}^{j},
$$


where $\chi_{i}^{j}=1$ if $i=j$ and 0 otherwise, $\delta_{T}$ is the depreciation rate of tangible capital, $X_{I, i}^{j}$ is investment in plant-specific intangible capital which is split among the locations in country $i$ that $j$ operates, and $X_{M}^{j}$ is the technology capital investment of multinational $j$ used in all locations in which $j$ operates. $^{7}$ The multinational takes as given sequences of prices $p_{t}$ and wages $W_{i t}$. The same wage rate is paid by all multinationals operating in $i$.

Dividends for the multinational companies (indexed by $j$ ) are equal to worldwide after-tax profits less net investment of tangible capital, $\sum_{i}\left(K_{T, i, t+1}^{j}-K_{T, i t}^{j}\right)$. Taxable profits are equal to sales less expenses, where the expenses are wage payments, tangible depreciation, and expensed investments on plant-specific intangible capital and technology capital. Taxable profits in country $i$ are taxed at rate $\tau_{p i}$. The capital stocks of the multinational in the next period are given by

$$
\begin{aligned}
K_{T, i, t+1}^{j} & =\left(1-\delta_{T}\right) K_{T, i t}^{j}+X_{T, i t}^{j} \\
K_{I, i, t+1}^{j} & =\left(1-\delta_{I}\right) K_{I, i t}^{j}+X_{I, i t}^{j} \\
M_{t+1}^{j} & =\left(1-\delta_{M}\right) M_{t}^{j}+X_{M, t}^{j}
\end{aligned}
$$

where $\delta_{I}$ and $\delta_{M}$ are depreciation rates of plant-specific intangible capital and technology capital.

\subsection{Households}

In each period $t$, households in country $i$ choose how much to consume $C_{i t}$, how much total labor to supply $L_{i t}$, and how much to borrow from abroad, $B_{i, t+1}-B_{i, t}$. Without loss of generality, I assume that households in $i$ own all of the equity shares of multinationals incorporated in $i$; thus, foreign borrowing and lending residually determine their net portfolio income. The maximization problem for the stand-in household is to

$$
\max _{\left\{C_{i t}, L_{i t}, B_{i, t+1}\right\}} \sum_{t} \beta^{t} N_{i t}\left[\log \left(C_{i t} / N_{i t}\right)+\psi \log \left(1-L_{i t} / N_{i t}\right)\right]
$$

7 To avoid having to account for clientele effects, I assume that all dividends are taxed at the same rate. 
subject to

$$
\sum_{t} p_{t}\left[C_{i t}+B_{i, t+1}-B_{i t}\right] \leq \sum_{t} p_{t}\left[\left(1-\tau_{l i}\right) W_{i t} L_{i t}+\left(1-\tau_{d}\right) D_{t}^{i}+r_{b t} B_{i t}+\kappa_{i t}\right]
$$

where $\beta \in(0,1)$ is the discount factor, $\psi \geq 0$ is a preference parameter governing disutility of labor, and the total population in $i$ is assumed to be proportional to the total number of locations $N_{i t}$. Without loss of generality, I assume a constant of proportionality of 1 between the number of people and the number of production locations within a country. Households take as given the sequence of returns on portfolio income $r_{b t}$, wage rates $W_{i t}$, prices $p_{t}$, and government transfers $\kappa_{i t}$. Labor is not mobile across countries but can be supplied to domestic or foreign companies. Taxes are levied on labor at rate $\tau_{l i} \cdot{ }^{8}$

\subsection{Competitive Equilibrium}

The competitive equilibrium in this model is defined as a set of prices $\left\{p_{t}, r_{b t}, W_{i t}\right\}$ and quantities $\left\{D_{i t}^{j}, Y_{i t}^{j}, K_{T, i t}^{j}, K_{I, i t}^{j}, M_{t}^{j}, L_{i t}^{j}, L_{i t}, C_{i t}, B_{i t}, X_{T, i t}^{j}, X_{I, i t}^{j}, X_{M t}^{j}\right\}$ that are consistent with the maximization problems of multinationals and households. In addition, markets must clear. The market-clearing condition for the labor market in each country $i$ is that

$$
\sum_{j} L_{i t}^{j}=L_{i t}
$$

The market-clearing condition for financial assets is that

$$
\sum_{i} B_{i t}=0
$$

The market-clearing condition for goods is that

$$
\sum_{i}\left\{C_{i t}+\sum_{j}\left(X_{T, i t}^{j}+X_{I, i t}^{j}\right)+X_{M, t}^{i}\right\}=\sum_{i, j} Y_{i t}^{j} .
$$

These conditions, along with the household budget constraints above, imply that government transfers in country $i$ satisfy this:

$$
\kappa_{i t}=\tau_{l i} W_{i t} L_{i t}+\tau_{d} D_{t}^{i}+\tau_{p i}\left\{\sum_{j}\left(Y_{i t}^{j}-\delta_{T} K_{T, i t}^{j}-X_{I, i t}^{j}\right)-W_{i t} L_{i t}-X_{M, t}^{i}\right\} .
$$

8 Since tax rates are constant, here I combine taxes on consumption and labor into the labor wedge $\tau_{l i}$. 
A crucial aspect of the competitive equilibrium in this model is the accumulation of nonrival technology capital because it plays an important role in determining the flows of inward and outward FDI. In countries that erect barriers to FDI - those with low values for $\sigma_{i}$-investments in technology capital must be made by domestic firms. If these countries have, in addition, high TFP or abundant locations, then companies will have incentives to build up large stocks of technology capital. In the event of a capital liberalization, those countries that are relatively closed and relatively large - in terms of $A_{i}$ and $N_{i}$ - would be the main suppliers of technology capital via FDI. In contrast, countries that are relatively open and small with regard to TFP and number of locations would take advantage of the newly accessible stocks of technology capital from abroad and would host the FDI.

\subsection{Accounting Measures}

Before deriving properties of the competitive equilibrium, I need to describe how to construct the national accounting statistics for the model. I use accounting measures that are also used in the empirical studies surveyed by Kose, Prasad, Rogoff, and Wei (2009).

Gross domestic product (GDP) for country $i$ in period $t$ is given by

$$
\mathrm{GDP}_{i t}=C_{i t}+\sum_{j} X_{T, i t}^{j}+N X_{i t},
$$

where $N X_{i}$ is net exports of goods and services by country $i$. Consumption and investment include both private and public expenditures. Intangible investments are expensed and therefore not included in the measure of GDP. In other words, GDP is not a measure of total output. GDP is lower because some investments are expensed.

To see this, consider a second way of calculating GDP: namely, to add up all domestic incomes. Specifically, if we sum compensation of households $W_{i} L_{i}$, total before-tax profits

of businesses operating in $i, Y_{i}-W_{i} L_{i}-\sum_{j}\left(\delta_{T} K_{T, i}^{j}+X_{I, i}^{j}\right)-X_{M}^{i}$, and tangible depreciation $\sum_{j} \delta_{T} K_{T, i}^{j}$, we then have GDP from the income side:

$$
\mathrm{GDP}_{i t}=Y_{i t}-X_{M, t}^{i}-\sum_{j} X_{I, i t}^{j}
$$


This sum has to be equal to the sum of products in (2.8). From (2.8) and (2.9), it is easy to calculate net exports as total output produced in country $i$ less the sum of consumption and all investments.

Next, add flows to and from other countries. Gross national product (GNP) is the sum of GDP and net factor income from abroad. Net factor receipts (NFR) are the sum of the FDI income of multinationals and the portfolio income of households: ${ }^{9}$

$$
\mathrm{NFR}_{i t}=\sum_{l \neq i}\left\{D_{l t}^{i}+K_{T, l, t+1}^{i}-K_{T, l t}^{i}\right\}+\max \left(r_{b t} B_{i t}, 0\right)
$$

Analogously, net factor payments (NFP) from $i$ to the rest of the world are the sum of FDI income of foreign affiliates in $i$ sent back to foreign parents and portfolio incomes of country $i$ that are sent to investors outside of $i$ :

$$
\mathrm{NFP}_{i t}=\sum_{l \neq i}\left\{D_{i t}^{l}+K_{T, i, t+1}^{l}-K_{T, i t}^{l}\right\}+\max \left(-r_{b t} B_{i t}, 0\right) .
$$

Adding net factor income to net exports and to GDP gives the current account (CA) and GNP:

$$
\begin{gathered}
\mathrm{CA}_{i t}=N X_{i t}+\mathrm{NFR}_{i t}-\mathrm{NFP}_{i t} \\
\mathrm{GNP}_{i t}=\mathrm{GDP}_{i t}+\mathrm{NFR}_{i t}-\mathrm{NFP}_{i t} .
\end{gathered}
$$

In the balance of payments, the current account must equal the financial account, which is the sum of new acquisitions abroad. For the model, the financial account for country $i$ is

$$
\mathrm{FA}_{i t}=\sum_{l \neq i}\left(K_{T, l, t+1}^{i}-K_{T, l t}^{i}\right)-\sum_{l \neq i}\left(K_{T, i, t+1}^{l}-K_{T, i t}^{l}\right)+\left(B_{i t+1}-B_{i t}\right),
$$

where the first term is net FDI by multinationals from $i$ abroad, the second term is the (negative) of net new investment by foreigners operating in $i$, and the third term is new

9 Equity in overseas operations is categorized as capital from direct investment when the ownership exceeds 10 percent. Otherwise, it is categorized as capital from portfolio investment. 
portfolio acquisitions by households from $i$. Empirical studies report regressions of per capita growth of GDP on FDI (or FDI relative to some measure of aggregate output), controlling for changes in other variables. The right-side variable of those regressions is the second term of (2.14).

\section{A Qualitative Assessment}

Now I describe, qualitatively, the equilibrium path of this economy as capital markets open. In order to make precise predictions about these paths in transition, I consider two countries, differing only in size, that agree to open their capital markets to each other at a prespecified date in the future. I examine how common measures of economic performance change between the time the liberalization is announced through the time it actually

occurs. In order to investigate the relationship between FDI and portfolio investment, I also compare a situation in which there are no restrictions on portfolio investments to one in which there are restrictions that are relaxed along with FDI restrictions. I find that country size and portfolio investment opportunities strongly affect the pattern of economic activity during transition to FDI openness, and I demonstrate that common measures of economic performance obscure the benefits of FDI openness.

\subsection{Additional Assumptions}

The propositions below assume that there are two countries of different sizes, where size is defined to be $N_{i t} A_{i t}^{1-(1-\phi)\left(\alpha_{T}+\alpha_{I}\right)}$ and thus depends on a country $i$ 's population and level of TFP. Both countries start out closed, and then both announce an FDI openness policy $\sigma_{i t}^{*}$ in $t=1$. In Fig. 1, I display the path of the degree of FDI openness $\left\{\sigma_{i t}\right\}$, which is assumed to be the same for both countries. After $t^{*}$, companies are allowed to produce at home and abroad.

I assume that $N_{i t}=N_{i}\left(1+\gamma_{N}\right)^{t}$ and $A_{i t}=\left(1+\gamma_{A}\right)^{t}$ for some fixed $N_{i}$ and $A_{i}$ and 
report results relative to historical trends, where $\gamma_{N}$ is the common trend growth rate in populations and $\gamma_{A}$ is the common trend growth rate in technologies. In other words, I divide all variables that grow (except labor inputs) by $\left(1+\gamma_{Y}\right)^{t}$, where

$$
\gamma_{Y}=\left(1+\gamma_{N}\right)^{\frac{1-(1-\phi)\left(\alpha_{T}+\alpha_{I}\right)}{(1-\phi)\left(1-\alpha_{T}-\alpha_{I}\right)}}\left(1+\gamma_{A}\right)^{\frac{1}{(1-\phi)\left(1-\alpha_{T}-\alpha_{I}\right)}}-1
$$

For labor inputs, I divide by $\left(1+\gamma_{N}\right)^{t}$. Lowercase letters are used to denote the detrended variables; for example, $c_{i t}=C_{i t} /\left[N_{i}\left(1+\gamma_{Y}\right)^{t}\right]$ and $l_{i t}=L_{i t} /\left[N_{i}\left(1+\gamma_{N}\right)^{t}\right]$. Throughout this section, the historical trend is assumed to be consistent with closed capital markets; therefore, for the equilibrium described below, $\sigma_{i 0}=0$ and $B_{i 0}=0 .{ }^{10}$

In order to make precise statements about the equilibrium paths, I make three additional assumptions. One concerns the degree of FDI openness: at $t=t^{*}+1, \sigma_{i t}^{*}$ is high enough so that the smaller country does not find it optimal to make any further expenditures in technology capital in $t>t^{*}$. A second assumption is that companies in the smaller country operate only domestically. ${ }^{11}$ In this case, I need only focus on FDI flows into the small country. Fig. 2 shows the path of inward FDI of that country, which peaks at $t^{*}$, one period before the restrictions are actually relaxed. For the model, the FDI investment by multinationals is summarized by the second term in (2.14), which is the net new investment in tangible capital.

My final assumption, which is relevant only for the case without portfolio restrictions, is to assume that households in the larger country receive an exogenous amount of income, denoted by $\epsilon_{t}$, between the periods $t=1$ and $t=t^{*}$ (which could be positive or negative). The income stream is such that the interest rate is constant and equal to its historical value for all periods $t=1, \ldots, t^{*}{ }^{12}$ In practice, the income needed to ensure a constant interest rate is tiny, but this assumption lets me make precise statements about a complicated

10 The equilibrium patterns do not change for $\sigma_{i 0}>0$ as long as $\sigma_{i 0}$ is below a particular threshold.

11 Relaxing this assumption complicates the mathematics but changes the results only slightly because the accumulated technology capital of the smaller country is lower than that of the larger country.

12 If $\epsilon_{t}=0$ for all $t$, then the equilibrium interest rate is nearly constant. For a plot of the interest rates with and without the income adjustment, see McGrattan (2012). 
dynamic path in an economy that is so close to the economy of interest (with $\epsilon_{t}=0$ ) that the paths cannot be easily distinguished when graphed. I refer to the related economy as the $\epsilon$-economy.

\subsection{Without Portfolio Restrictions}

I begin this qualitative exercise by exploring what happens in the two countries when restrictions on portfolio investments are relaxed immediately, but restrictions on FDI are relaxed after a prespecified date $t^{*}$.

Proposition 1. The small country's output, labor, and capital stocks in the $\epsilon$-economy are at or below their historical trends between $t=1$ and $t=t^{*}$, whereas its consumption is above trend. The reverse is true for the large country.

Proof. Suppose that in $t=1$, consumption $c_{s t}$ in the small country, with index $i=s$, rises relative to its historical trend, $c_{s 1}>c_{s 0}$. Then, between $t=2$ and $t=t^{*}, c_{s t}=c_{s 1}$ since $r_{b t}$ is constant by the choice of the $\left\{\epsilon_{t}\right\}$ adjustment. To be consistent with the intertemporal condition for asset holdings, this rate of interest has to equal $\left(1+\gamma_{y}\right) / \beta-1$, where $\gamma_{y}$ is the rate of growth of per capita output, $\gamma_{y}=\left(1+\gamma_{Y}\right) /\left(1+\gamma_{N}\right)-1$, and $\beta$ is the household's discount factor.

From the intratemporal first-order condition of households (with log preferences), we know that

$$
\frac{y_{s t}}{l_{s t}}=\frac{y_{s t}^{d}}{l_{s t}^{d}} \propto \frac{c_{s t}}{1-l_{s t}}, \quad t=1, \ldots, t^{*},
$$

where $y_{s t}^{d}$ is the output of domestic companies (indexed by $d$ ) in the small country. The first equality in (3.1) follows from the assumption that countries are initially closed to all foreign investment, so all labor is supplied to domestic companies and all output is produced by them. With capital stocks initially fixed and consumption higher in period $t=1$, we know that $l_{s 1}<l_{s 0}$ and $y_{s 1}<y_{s 0}$ if (3.1) holds. With capital fixed, we also know that labor falls by more than output in $t=1$. 
In period $t=2$, output and labor must fall further relative to the historic trend because domestic capital stocks fall between the first and second periods. To see this, note that the capital-output ratio is pinned down by the return $r_{b t}$. If this return in the second period is equal to $\left(1+\gamma_{y}\right) / \beta-1$, then the capital-output ratios have to be equal to their historical levels (in $t=0$ ). This fact plus the production technologies implies that labor productivity in the second period must also be at its historical level. Thus, from (3.1), we know that $y_{s 2}<y_{s 1}$ and $l_{s 2}<l_{s 1}$, since labor productivity in the second period is below labor productivity in the first.

Since the interest rate does not change between $t=2$ and $t^{*}$, we know that $y_{s t}=y_{s 2}$ and $l_{s t}=l_{s 2}$ for $t \leq t^{*}$. This follows from the intratemporal condition and the fact that capital-output ratios and consumptions relative to trend are constant.

The arguments made for the small country can also be made for the large country. However, because the global resource constraint must hold, the paths relative to trend for the large country must be reversed. In other words, if consumption for the small country is above its historical trend from $t=1$ to $t=t^{*}$, then consumption for the large country must be below its historical trend. This follows because output and investment are below (or above) trend by the same percentage over the period from $t=2$ to $t=t^{*}-1$, since capital-output ratios are constant. If consumption in both countries were above trend and output less investment in both countries below trend, then the global resource constraint would be violated.

Finally, we can easily show that consumption is initially above trend in the small country, which is the recipient of future FDI, and initially below trend for the large country, which is the source of the FDI. This follows from the fact that effective TFP is higher in the small country when FDI, and hence foreign technology capital, is allowed in. For the large country there is no change in effective TFP because small country firms only produce domestically. 
This proof of Proposition 1 is instructive in that it implies specific patterns for the key macroeconomic aggregates in the transition period between the announcement and the enactment of the policy to relax restrictions on FDI. Fig. 3 shows the equilibrium paths for consumption, output, and labor in the small country (left panels) and the large country (right panels). The scale of the figures in the left panels of Fig. 3 are comparable to those in the right panels, indicating that the relaxed FDI restrictions have a relatively larger impact on the small country.

Fig. 3 shows that consumption in the small country rises above its historical trend at the announcement of the new policy, stays on a new higher trend until the restrictions are actually relaxed, and then rises further after $t^{*}$ when the interest rate is no longer constant. At the same time, consumption in the large country is below its historical trend, but ultimately rises above trend as global production expands; after $t=t^{*}$, the multinationals in the large country are able to produce at home and abroad.

Equilibrium paths for output and labor relative to their historical trends are shown in the bottom half of Fig .3. I put output and labor on the same graph in order to show that in the period from $t=2$ to $t=t^{*}$, they are below trend by the same percentage. When restrictions are relaxed, output in the small country rises relatively more than labor because TFP and capital are both higher. As with consumption, I find that output and labor in the large country, which by assumption has no inward FDI, is little changed.

Equilibrium paths for the capital stocks are shown in the top half of Fig. 4. The domestic capital stocks fall for one period after the announcement and then remain flat until the policy is actually enacted. After $t=1$ and before the policy goes into effect, capital-output ratios and labor productivity remain at their historical trends. When the policy is changed, investment in the technology capital of domestic companies ceases. At this point, the optimal policy is to leave it to foreign multinationals to invest in technology 
capital. Total tangible and plant-specific intangible capital stocks rise and remain high because foreign companies are now investing in the small country.

With multinationals investing in intangible capital, output (shown in Fig. 3) is not equal to GDP or GNP, which are typical measures of economic performance used in crosscountry empirical studies. The following proposition qualifies the equilibrium paths of these series in the transition.

Proposition 2. The small country's GDP and GNP in the $\epsilon$-economy initially, after the announcement, rise above their historical trends and then fall below trend between $t=2$ and $t=t^{*}$. The reverse is true for the large country.

Proof. Recall the definitions of GDP and GNP in (2.9) and (2.13). In the first period, when the policy is announced, net factor incomes for the period are already determined; therefore, GNP must equal GDP. To show that both are above their historical trends in the small country in $t=1$, I must show that intangible investments of domestic firms (indexed by $d$ ) in the small country (indexed by $s$ ) fall by more than output, since GDP is defined as output less the sum of investment in plant-specific intangible capital and technology capital. This is shown as follows:

$$
\begin{aligned}
\frac{x_{I, s 1}^{d}-x_{I, s 0}^{d}}{x_{I, s 0}^{d}} & =\frac{1+\gamma_{Y}}{\delta_{I}+\gamma_{Y}}\left(\frac{k_{I, s 2}^{d}-k_{I, s 0}^{d}}{k_{I, s 0}^{d}}\right) \\
& =\frac{1+\gamma_{Y}}{\delta_{I}+\gamma_{Y}}\left(\frac{y_{s 2}^{d}-y_{s 0}^{d}}{y_{s 0}^{d}}\right) \\
& <\frac{1+\gamma_{Y}}{\delta_{I}+\gamma_{Y}}\left(\frac{y_{s 1}^{d}-y_{s 0}^{d}}{y_{s 0}^{d}}\right),
\end{aligned}
$$

where the first equality uses the capital accumulation equation after detrending all variables, the second equality follows from the fact that the capital-output ratio in the second period is equal to the historical capital-output ratio, and the inequality follows from Proposition 1. Since $\delta_{I} \leq 1$, plant-specific intangible investment must fall by more than output. 
The same argument can be made for technology capital. Therefore, GDP and GNP are both above trend in $t=1$.

In the second period, since the capital-output ratios are at their historical trends, GDP in the small country must be below its own trend by the same amount as output. In $t=t^{*}$, GDP falls further below its historical trend than output has fallen because investment of foreign multinationals in both tangible and plant-specific intangible capital rises above zero. GDP is lower because of the rise in plant-specific intangible investment.

The path of GNP depends on the path of portfolio investment from abroad. Since there are no portfolio restrictions, the small country borrows as soon as the policy change is announced and must make bond repayments thereafter. Thus, GNP is above GDP in $t=2$ and below in $t=3, \ldots, t^{*}-1$, with the difference between GNP and GDP equal to the interest payments $r_{b t} b_{i t}$.

In the transition period, the pattern of debt can be determined from net exports which are equal to the change in debt holdings less interest payments. Net exports are equal to GDP less domestic consumption and investment - and all three of these variables are constant relative to their historical trends between $t=2$ and $t=t^{*}-1$. Thus, net exports must also be constant relative to its historical trend.

The arguments made for the small country can also be made for the large country, but the direction of change is reversed for the periods $t=1$ to $t=t^{*}$.

The bottom half of Fig. 4 shows the equilibrium paths for GDP and GNP. As the propositions above show, both GDP and GNP in the small country are above trend initially. But in $t=2$, small country GDP has dropped below trend by the same amount as true output and stays constant relative to that historical trend until intangible investment by foreign multinationals rises significantly. GNP falls throughout the preliberalization period because the small country is paying portfolio income to households abroad. The 
large country paths are shown for comparison; as in the case of output and labor, there is a smaller impact of FDI openness in the large country.

A comparison of Fig. 2 and the bottom left panel of Fig. 4 clearly illustrates one of the main messages of the paper, namely, that when foreign direct investment is high, GDP is low. The reason is simple: FDI is high because foreign tangible investment is high, GDP is low because foreign plant-specific intangible investment is high, and both investments are high when countries are open to FDI. After liberalization, GDP in the small country is above its historical trend because it exploits the technology capital of the large country. If there is a reversal of policy after $t^{*}$, the small country would have to rebuild its own technology capital, which is costly. Furthermore, the intangible investments that they would have to make would result in low measured profits and, thus, low national income.

The rise in consumption and leisure in the small country hosting the new FDI is indicative of a positive welfare gain to openness, if the welfare gain is measured as the consumption increase necessary to keep the small country indifferent between remaining closed and being open. Assuming that countries have good measures of consumption, this suggests that empirical studies could use this alternative measure of economic performance instead of the ones typically used, namely, per capita GDP or GNP. I will show next that the usefulness of consumption as a proxy for economic gains depends on whether there are restrictions on portfolio investments. So far, I have assumed that there are no restrictions.

\subsection{With Portfolio Restrictions}

Now I consider what happens if restrictions on portfolio and foreign direct investments are relaxed together. In this case, $B_{i, t+1}=0$, for both $i$ and $t=1, \ldots, t^{*}$. With $\sigma_{i t}=0$ over the same period, the two economies are initially effectively closed, and the only changes in the time series are due to the anticipation of a future relaxation of the capital accounts.

Proposition 3. The small country's output and labor with full capital account restrictions 
are below their historical trend between $t=1$ and $t=t^{*}$. The reverse is true for the large country.

Proof. If, in period $t=1$, consumption in the small country rises relative to its historical trend, $c_{s 1}>c_{s 0}$, then the intratemporal first-order condition of households in (3.1) implies that labor and output fall initially. With capital fixed, labor falls more than output.

With no borrowing or lending allowed across countries, total investment in period $t=1, y_{s 1}-c_{s 1}$, must be below trend. With returns equated across assets, investment in all three types of assets - tangible capital, plant-specific intangible capital, and technology capital - must also be below trend.

In period $t=2$, output and labor must fall further because domestic capital stocks are lower between the first and second periods when investment in $t=1$ is below trend. Households cannot borrow from abroad; thus, output, investment, and labor continue to fall until $t=t^{*}$, and net exports remain equal to zero until the restrictions on FDI are relaxed.

Again, the same arguments can be made for the large country, but because the global resource constraint must hold, the paths relative to trend for the large country must be reversed. Because the small country is the recipient of future FDI while the large country is its source, the initial consumption in the small country must be above its historical trend, and the initial consumption in the large country must be below. Otherwise, the global resource constraint would be violated.

\subsection{A Comparison}

The two situations, with and without portfolio restrictions, are compared in Fig. 5. Clearly, the ability to borrow from abroad affects both an economy's transition to FDI openness and its future levels of activity. Without this ability, the adjustments are slow before $t=t^{*}$, but rapid when restrictions on capital accounts are relaxed. 
If portfolio investments are restricted, the economic benefits of the new policy are not easily detectable - either in terms of improved consumption and welfare or in terms of improved production and employment - until after a threshold degree of openness has been reached.

The results in Figs. 3-5 shed light on the central puzzle. According to standard neoclassical theory, countries with faster productivity growth should attract more foreign capital, but observed capital flows are not consistent with this prediction. Empirical studies find that countries with lower GDP and TFP growth receive most of the capital inflows. In the simple two-country version of the model with countries differing in size, I find this too. To be specific, let me define measured TFP as

$$
\operatorname{TFP}_{i t}=\frac{\mathrm{GDP}_{i t}}{K_{T, i t}^{1 / 3} L_{i t}^{2 / 3}}
$$

where $K_{T, i t}$ is the total tangible capital in country $i$. As in the case of GDP, measured TFP is abnormally low when inward FDI is abnormally high. This is true even if true TFP does not change. Thus, care must be taken when diagnosing economies with low or slow-growing GDP and TFP.

In McGrattan (2012), I show how the results change as I vary the length of the transition to openness - the time delay between policy announcement and policy enactment - the relative sizes of countries, the maximal degree of openness, and the share of income that goes to technology capital. The qualitative features shown in Figs. 3-5 are not altered.

\section{A Quantitative Assessment}

Next, I consider more realistic choices for the time paths governing the relative size and degrees of openness in the world economy and the number of countries. I enlarge the model to a 104-country version parameterized with data from the World Bank's World 
Development Indicators (WDI), for the period 1980-2005. ${ }^{13}$ After demonstrating that the model generates empirically consistent employment shares of affiliates at home and abroad, I simulate transition paths and get a result like those of many other studies: no systematic pattern between the degree of FDI openness and the level of economic growth predicted by the model. ${ }^{14}$ Going beyond other studies, I also estimate the growth impact and welfare gains, for each country in the sample, when I unilaterally relax capital market restrictions. I find that the boost to annual per capita GDP growth over the period 1980-2005 is large, as much as 7 percentage points. I find that the welfare gains are also large, as much as 460 percent in consumption-equivalent units. Both effects are inversely related to country size.

\subsection{Model Specifications}

Inputs in the larger version of the model are chosen so that it generates trends in inward FDI to GDP that mimic the trends in the data. Because the focus is on trends, a period is defined as five years. The choice of 104 countries is dictated by data availability on inward FDI, net portfolio investment, GDP, and population. I assume that countries have four differences: (1) relative technology levels $A_{i}$, which I assume are on trend and chosen so that real GDP per capita in 1980 is the same in the model and the data; (2) populations $N_{i t}$, which are taken directly from the WDI data; (3) degrees of FDI openness $\sigma_{i t}$, which are chosen so that the ratio of inward FDI to GDP in the model has the same trend as a moving average of the actual series; and (4) the number of periods that international

13 For data sources, see Appendix A. See Appendix B and McGrattan (2012) for details on the computational methods. Note that in the 104-country version of the model, I allow for small quadratic costs of adjusting capital stocks. This approach avoids numerical difficulties due to binding nonnegativity constraints on investments.

14 Many factors are left out of the analysis here in order to highlight the impact of relaxing capital market restrictions on economic performance. Sensitivity analysis in McGrattan (2012) shows that the main results are not overturned if changes in other factors are included. 
borrowing $B_{i t}$ is held at zero, which I denote as $T_{c}$ and set by comparing net portfolio investments in the model and the data. ${ }^{15}$

The implied productivities, $A_{i}$, and the path for populations, $N_{i t}$, at five-year intervals are reported in Table 1 for all countries $i$ in the sample (along with the country codes used in the following figures). All estimates are relative to the United States, which is normalized to be 100. After 2005, I assume that the populations relative to that of the United States stay at their 2005 level. As the values in the table indicate, the dispersion in country relative size is large, which is not surprising given the wide range of TFPs and populations.

The path of the degree of openness, $\sigma_{i t}$, is reported in Table 2 for all countries $i$ along with the number of periods during which international borrowing is held at zero. For many of the countries, using a step function for the sequence $\sigma_{i t}$ generates a realistic level and time series path for the ratio of FDI to GDP. Thus, the time path used in the two-country example is not atypical. ${ }^{16}$

For all other parameters, I use estimates from my 2010 study with Prescott of the U.S. current account, which are listed in Table $3 .{ }^{17}$ To ensure that none of the results rest critically on any of these choices, I have also done an extensive sensitivity analysis. (See McGrattan, 2012.)

In Appendix B and McGrattan (2012), I provide details on the first-order conditions of the maximization problems and the methods used for computing equilibria in this model with many states. The main innovation here is the use of parallel processors, one for each country.

15 As before, measured TFPs are time varying, since they depend on the time paths of population and technology capital.

16 Codes are available at my website for generating all inputs and outputs of the model.

17 Averages are used for time-varying tax rates. 


\subsection{Implications for Employment Shares}

Before turning to the main quantitative result, I first check to see if it generates realistic employment shares between domestic and foreign firms. I do this because I have abstracted from many factors that differentiate countries, most importantly for the purposes here, their geography, language, and trade policies, which potentially affect these shares. I find that despite those abstractions, the model's employment predictions are quite good.

In Figs. 6-8, I show evidence from three sources: the Organisation for Economic Cooperation and Development (OECD) statistics on inward activity of multinationals and employment (OECD, 2010a, 2010b, 2010c), the survey of foreign affiliates in the United States from the Bureau of Economic Analysis (BEA) (U.S. Department of Commerce, 2007), and the BEA's survey of U.S. affiliates abroad (U.S. Department of Commerce, 2008). I use data on manufacturing employment, since that measure is available and most relevant; service industries have been a much smaller share of multinational operations to date.

Fig. 6 compares for each country the predicted and actual employment under foreign control as a share of the country's total employment. Data are available for 17 OECD countries. The graph shows that the model does well along this dimension: the correlation between the predicted and actual shares is 0.82 .

Fig. 7 compares the predicted and actual employment of foreign affiliates in the United States by country of origin. The countries in the figure cover 88 percent of all foreign employment in U.S. manufacturing. In the model, these same countries cover 86 percent of all foreign employment in the United States. The correlation between the predicted and actual shares is 0.80 .

Fig. 8 compares the predicted and actual employment of U.S. affiliates abroad relative to employment in the host country. The model underpredicts employment shares in Canada and Ireland, but does a reasonably good job given that geography, language, and trade 
agreements are not modeled. The model overpredicts the employment share of BelgiumLuxembourg, a country with few people but a high inward FDI to GDP ratio. Despite these deviations, the correlation between the predicted and actual shares is still high at 0.68 .

Overall, the predicted and actual employment shares match up well.

\subsection{Current Predictions}

Since the parameterized model does well in predicting employment shares, we can expect other predictions related to foreign investment to be at least reasonable. For the central issue here - the relationship between FDI openness and growth - the model predicts an economically insignificant relationship, as many empirical studies have found.

Fig. 9 is the analogue of Lucas's (2009) Fig. 2, which compares countries doing a little and a lot of trade. Here, I distinguish instead between countries doing a little or a lot of inward FDI. The $x$-axis of Fig. 9 shows the initial real GDP per capita relative to the level of the country parameterized to match U.S. observations. The $y$-axis is the annual growth rate in real GDP per capita over the period 1980-2005. This rate is relative to the growth rate of the country parameterized to match U.S. observations. Thus, an annual growth rate of zero implies that a country is growing at the same rate as the country matched to the United States. Rates above zero imply that the country is catching up to the U.S. level of per capita GDP, and rates below zero imply that it is falling behind. I use a cutoff for the average FDI to GDP of 1.8 percent and identify only countries that are above it, which is half of the sample. Other cutoffs for FDI could be used, and I could replace growth in GDP by growth in TFP, but the message would be the same: the data show no obvious relationship between capital restrictions and economic performance.

Another way to demonstrate this result is by way of a cross-country regression of 
growth on initial per capita GDP and the ratio of FDI to GDP. ${ }^{18}$ In Table 4, I report the results of such a regression for both the data and the model. The coefficient of interest is $a_{2}$. This coefficient is 0.052 in the data, but is not significantly different from zero. In the model, the estimate is 0.046 with a standard error smaller than that in the data, but it is not economically significant. If I double the FDI to GDP ratio from 2 percent (which is close to the median in my sample) to 4 percent, the predicted change in the growth rate for real GDP per capita relative to the U.S. growth rate remains less than 0.1 percentage point. ${ }^{19}$

\subsection{Potential Gains}

The lack of a robust and economically significant relationship between FDI openness and growth does not necessarily mean that the effects of FDI openness are not positive and large. To demonstrate, I compute the economic impact of relaxing capital market restrictions almost completely for one country at a time. I estimate the benefits in terms of higher GDP growth and welfare and find that they can be huge, especially for small countries.

More specifically, I run the following counterfactual experiment: for each country $i$, I increase the $\left\{\sigma_{i t}\right\}$ to 0.95 for all periods after 1980, and I remove all restrictions on portfolio investments. This choice is above the maximum value for the benchmark model, which is 0.92 in the case of Singapore, and a realistic upper bound since most countries have policies forbidding foreign investment in industries that are crucial for the military and national security. ${ }^{20}$ In each case, I calculate the growth in per capita GDP less the growth rate computed in the benchmark model and the consumption-equivalent gain, that

18 Many of the studies surveyed by Kose, Prasad, Rogoff, and Wei (2009) include other control variables about which the model is silent. But researchers have found that adding them reduces the already small coefficients on the ratio of FDI to GDP.

19 In McGrattan (2012), I analyze variations on the growth regression shown in Table 4 . In all cases, I find that the predicted change in the growth rate is economically insignificant.

20 I cannot raise $\sigma_{i t}$ to 1 for two reasons. First, at 1 , there is an indeterminacy in terms of who should produce technology capital. Second, it is difficult numerically to raise $\sigma_{i t}$ much higher than 0.95 with many countries near corners in terms of investment. 
is, the increase in consumption needed to keep the country indifferent between the old and new policy.

Fig. 10 shows the prediction for GDP growth when countries are close to completely open relative to that of the benchmark parameterization. ${ }^{21}$ The differences in the predicted growth rates are plotted relative to country size (in log scale). As expected from the earlier propositions, there is an inverse relationship between a host country's growth following capital market liberalization and its relative size. In almost all cases, the boost in growth in transition is substantial, with the highest annual estimates around 7 percentage points. ${ }^{22}$

Fig. 11 shows the predicted welfare gains for each country unilaterally opening their capital markets. As with growth, there is an inverse relationship between gains and the country's relative size, which is close to linear in logarithms. The smallest potential gain is found for the United States, at a 4 percent increase in consumption, and the largest gain for the Solomon Islands, at a 460 percent increase. If we compare two countries close to the best-fit line in Fig. 11-say, Great Britain and Botswana-we find that a country smaller by a factor of 300 has a welfare gain that is 11 to 12 times larger. In other words, for small countries, the potential gains to openness are huge. ${ }^{23}$

\section{Conclusion}

Here, I have studied the equilibrium paths of a multicountry dynamic general equilibrium model as countries relax restrictions on portfolio and foreign direct investment. By taking account of a transition period, the model reconciles theoretical claims that allowing FDI leads to higher growth and welfare for host countries with the lack of robust empirical

\footnotetext{
21 Numerical values for the results in Figs. 10 and 11 are reported in Table 2 in McGrattan (2012).

22 As in the basic neoclassical growth model, increased growth rates in my model are temporary as countries catch up. See Henry (2007).

23 The inverse relation between gains and size is also found in work by Ramondo and Rodríguez-Clare (forthcoming), who estimate the gains of moving from autarky to current-day capital and current account restrictions for 19 OECD countries.
} 
evidence for such benefits. In the model, benefits to FDI openness are large, but not until some threshold of openness is reached.

This result implies at least two research challenges. More work is required to delineate the characteristics of the openness threshold. And the standard method of analyzing the effects of FDI openness must be abandoned. After all, even using the method here, on the data generated by my model, results in the mistaken conclusion that relaxing restrictions on capital movements is not beneficial to the host country. 


\section{Appendix A. Data Sources}

The World Bank's World Development Indicators is the source of individual-country data used in this study. All countries with complete time series for the period 1980-2005 are included. $^{24}$ (The complete list of countries is shown in Tables 1 and 2.) Specifically, I construct the ratio of inward FDI relative to GDP and real GDP per capita using the following variables (with WDI codes in parentheses):

- Foreign direct investment, net inflows, in current U.S. dollars (BX.KLT.DINV.CD.WD);

- Portfolio investment in current U.S. dollars (BN.KLT.PTXL.CD);

- GDP in current U.S. dollars (NY.GDP.MKTP.CD);

- GDP in constant 2000 U.S. dollars (NY.GDP.MKTP.KD);

- Total population (SP.POP.TOTL).

The OECD and the BEA are the sources of data used to construct employment shares of foreign affiliates shown in Figs. 6-8. Specifically, I use the following:

- Fig. 6: OECD.Stat Inward activity of multinationals (and, as a supplementary source, the OECD Factbook 2010);

- Fig. 7: FDIUS Establishment Data for 2002, Table A1.9, has employment of foreignowned establishments in the United States by country;

- Fig. 8: USDIA 2004 Final Benchmark Data, Table I.H3, has employment of affiliates, and the OECD STAN database for Structural Analysis has total manufacturing employment in the host country.

24 See McGrattan (2012) for results based on a subsample of the 104 countries, namely, those with complete inward FDI data (variable 4555) for the period 1980-2005 in the International Monetary Fund's Balance of Payments (IMF, 1980-2010). 


\section{Appendix B. Computational Methods}

Here, I briefly describe the two main numerical issues that arise in computing equilibria for the 104-country version of the model: the large dimensionality of the state space and the nonnegativity constraint on investment decisions. ${ }^{25}$

The issue of dimensionality arises because the investment decisions of firms in one country affect decisions in all other countries. To handle this issue, I used a parallel computer and a code that uses the message passing interface (MPI). An initial guess is made for the vector of interest rates, wages in all countries, and transfers in all countries. If there are $I$ countries and $T$ time periods, a fixed point must be found for $(2 I+1) T-1$ prices and transfers. The guess is distributed by the master processor to all slave processors. Given prices and transfers, equilibrium quantities are computed on the slave processors, passed back to the master, and the guess for the prices and transfers is updated. A fixed point in quantities must also be solved at each iteration. This is done with a standard Newton method, although I have found that analytical derivatives of the Jacobians are necessary to avoid very slow computations given the large number of unknowns being computed. A fixed point must be found for $(2 I+4) T$ quantities that include consumptions, labor supplies, bond holdings, investments in technology capital, $I$ investments in tangible capital, and $I$ investments in plant-specific intangible capital for each period. In all, $(4 I+5) T-1$ prices and quantities are computed.

The other issue is, again, the nonnegativity of investment decisions. As small countries relax capital restrictions and let technology capital flow in from abroad, the returns to investing in their own technology capital fall - possibly nonmonotonically, but ultimately to zero. With a large number of countries in the model, it is difficult to apply standard penalty function methods to avoid negative investments. Instead, I allow for (small) quadratic adjustment costs in the accumulation equations (2.5)-(2.7) to aid the solution of the fixed points in prices and quantities. For countries that are close to the corner at the start of the simulation (which is matched up to 1980 observations), I assume that they are at the corner and set the appropriate investments to zero.

25 For full details of the methods used and equations solved, see McGrattan (2012). 


\section{References}

Aoki, K., Benigno, G., Kiyotaki, N., 2009. Adjusting to capital account liberalization. Manuscript, Princeton University.

Brynjolfsson, E., Hitt, L. M., Yang, S., 2002. Intangible assets: Computers and organizational Capital. Brookings Papers on Economic Activity: Macroeconomics 1: 137-199.

Burstein, A. T., Monge-Naranjo, A., 2009. Foreign know-how, firm control, and the income of developing countries. Quarterly Journal of Economics 124, 149-195.

Caballero, R. J., Farhi E., Gourinchas, P.-O., 2008. An equilibrium model of "global imbalances" and low interest rates. American Economic Review 98, 358-393.

Corrado, C., Hulten, C. R., Sichel, D.E., 2005. Measuring capital and technology: An expanded framework, In: Corrado, C., Haltiwanger, J., Sichel, D. (Eds.), Measuring Capital in the New Economy. University of Chicago Press, Chicago.

Görg, H., Greenaway, D., 2004. Much ado about nothing? Do domestic firms really benefit from foreign direct investment? World Bank Research Observer 19, 171-197.

Gourinchas, P.-O., Jeanne, O., 2006. The elusive gains from international financial integration. Review of Economic Studies 73, 715-741.

Hall, R. E., 2000. E-capital: The link between the stock market and the labor market in the 1990s. Brookings Papers on Economic Activity 2, 73-118.

Henry, P. B., 2007. Theory, evidence, and speculation. Journal of Economic Literature $45,887-935$.

International Monetary Fund (IMF), 1980-2010. Balance of Payments, www.imfstatistics. org/bop.

Javorcik, B. S., 2004. Does foreign direct investment increase the productivity of domestic firms? In search of spillovers through backward linkages. American Economic Review $94,605-627$.

Kose, M. A., Prasad, E., Rogoff, K., Wei, S.-J., 2009. Financial globalization: A reappraisal. IMF Staff Papers 56, 8-62.

Kose, M. A., Prasad, E., Taylor, A. D., 2011. Thresholds in the process of international financial integration. Journal of International Money and Finance 30, 147-179. 
Lev, B., Radhakrishnan, S., 2005. The valuation of organization capital, In: Corrado, C., Haltiwanger, J., Sichel, D. (Eds.), Measuring Capital in the New Economy. University of Chicago Press, Chicago.

Lucas, R. E., Jr., 1978. On the size distribution of business firms. Bell Journal of Economics 9, 508-523.

Lucas, R. E., Jr., 2009. Trade and the diffusion of the Industrial Revolution. American Economic Journal: Macroeconomics 1, 1-25.

McGrattan, E. R., 2012. Technical appendix: Transition to FDI openness-Reconciling theory and evidence. Research Department Staff Report 455, Federal Reserve Bank of Minneapolis.

McGrattan, E. R., Prescott, E. C., 2005. Taxes, regulations, and the value of U.S. and U.K. corporations. Review of Economic Studies 72, 767-796.

McGrattan, E. R., Prescott, E. C., 2009. Openness, technology capital, and development. Journal of Economic Theory 144, 2454-2476.

McGrattan, E. R., Prescott, E. C., 2010. Technology capital and the U.S. current account. American Economic Review 100, 1493-1522.

Mendoza, E. G., Quadrini, V., Ríos-Rull, J. V., 2009. Financial integration, financial development and global imbalances. Journal of Political Economy 117, 371-416.

Nakamura, L., 2003. A trillion dollars a year in intangible investment and the new economy, In: Hand, J. R. M., Lev, B. (Eds.), Intangible Assets: Values, Measures, and Risks. Oxford University Press, New York.

National Science Foundation, 2012. National Patterns of R\&DD Resources 2009 Data Update, Division of Science Resources Statistics, Arlington, VA.

Organisation for Economic Co-operation and Development, 2010a. OECD.Stat, Inward Activity of Multinationals by Industrial Sector, Activity of Multinationals, www.source oecd.org.

Organisation for Economic Co-operation and Development, 2010b. OECD.Stat, STAN Database for Structural Analysis, Main Economic Indicators, www.sourceoecd.org.

Organisation for Economic Co-operation and Development, 2010c. OECD Factbook 2010, Employment in Foreign Affiliates, www.oecd-ilibrary.org. 
Ramondo, N., 2010. A quantitative approach to multinational productions. Manu- script, University of Texas at Austin.

Ramondo, N., Rodríguez-Clare A., 2010. Growth, size, and openness: A quantitative approach. American Economic Review, Papers and Proceedings 100, 62-67.

Ramondo, N., Rodríguez-Clare, A., forthcoming. Trade, multinational production, and the gains from openness. Journal of Political Economy.

U.S. Department of Commerce, Bureau of Economic Analysis and U.S. Bureau of the Census, 2007. Foreign Direct Investment in the United States: Establishment Data for 2002. U.S. Government Printing Office, Washington, DC.

U.S. Department of Commerce, Bureau of the Census, 2010. Statistical Abstract of the United States. U.S. Government Printing Office, Washington, DC.

U.S. Department of Commerce, Bureau of Economic Analysis, 2008. U.S. Direct Investment Abroad: 2004 Final Benchmark Data. U.S. Government Printing Office, Washington, DC.

World Bank Group, 1960-2010. World Development Indicators, www.worldbank.org. 
Figure 1. Degree of Openness for Both Countries over Time in the Two-Country Model

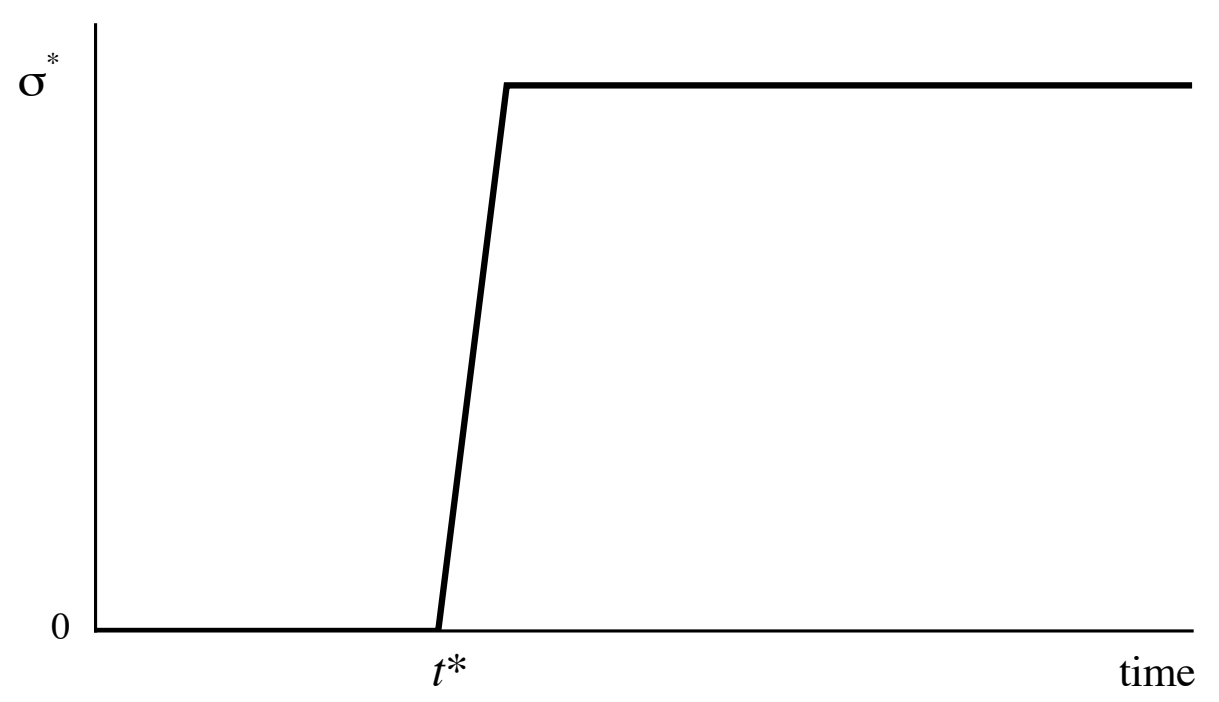

Figure 2. Inward FDI of the Small Country over Time in the Two-Country Model

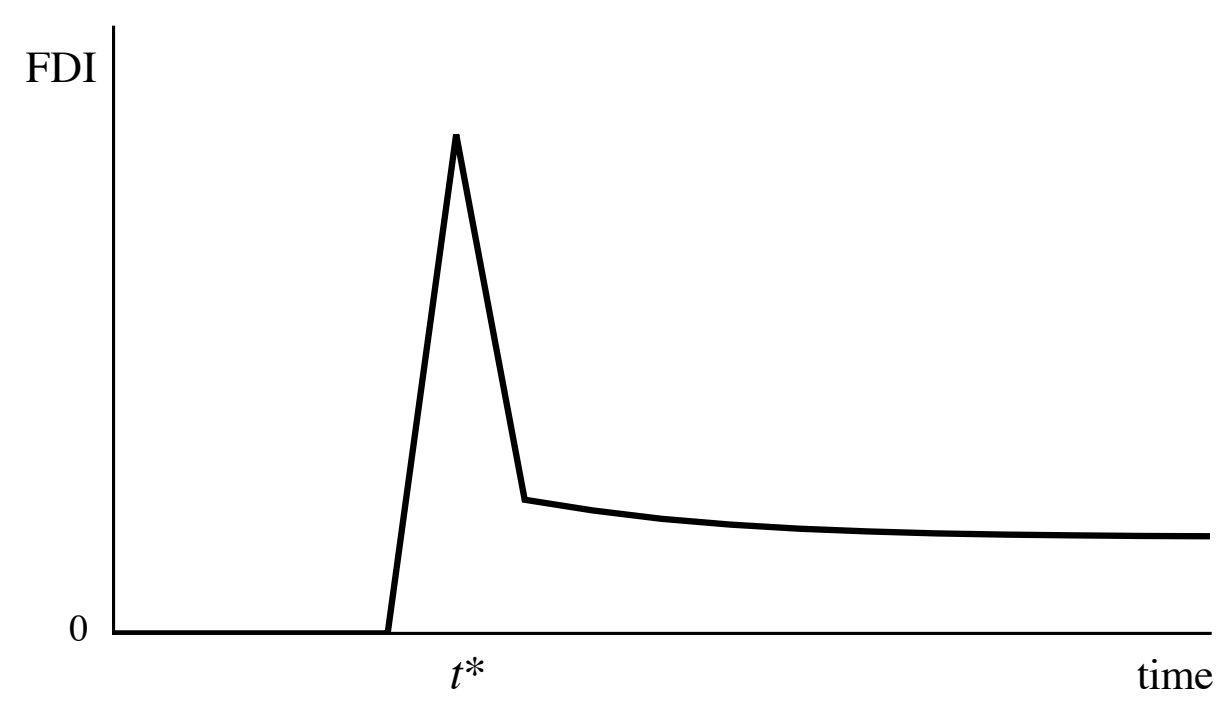


Figure 3. Detrended Consumption, Output, and Labor over Time in the Two-Country Model without Portfolio Restrictions (initial steady state $=100$ )

A. Small Country
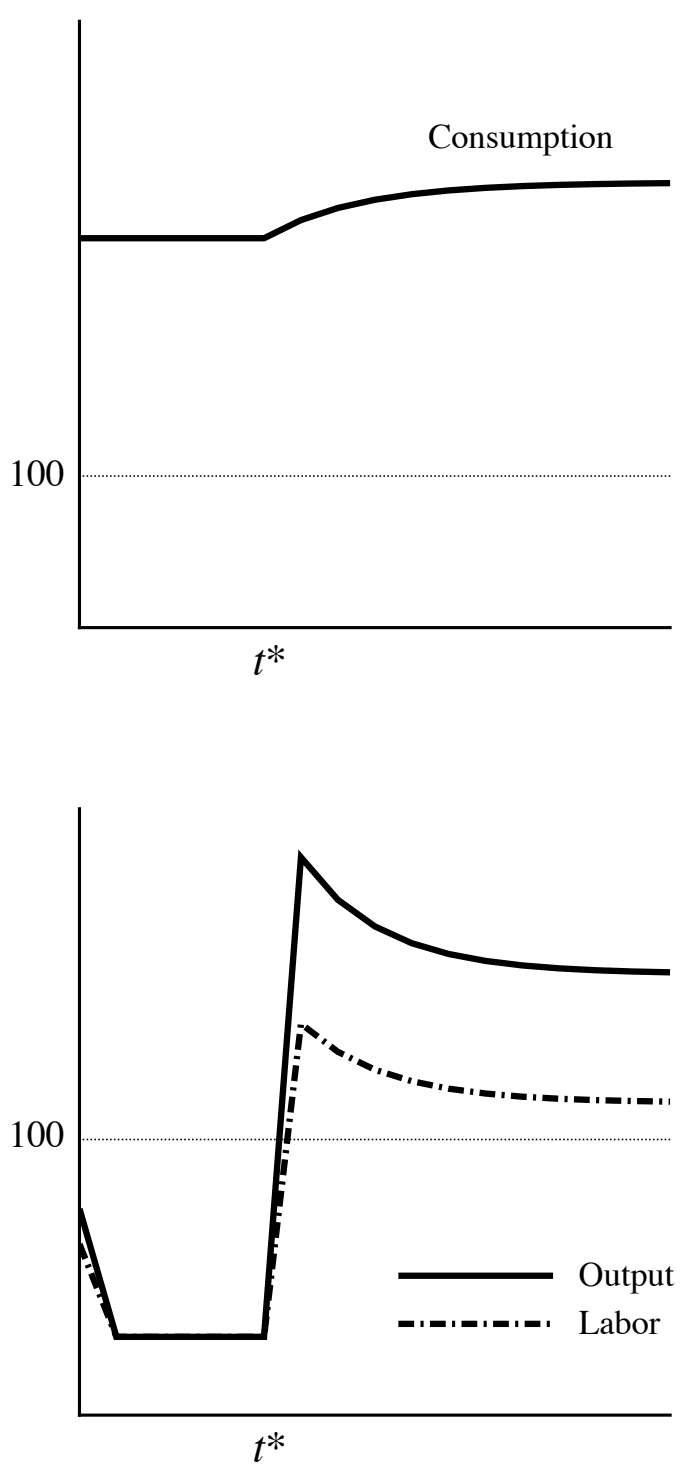

B. Large Country
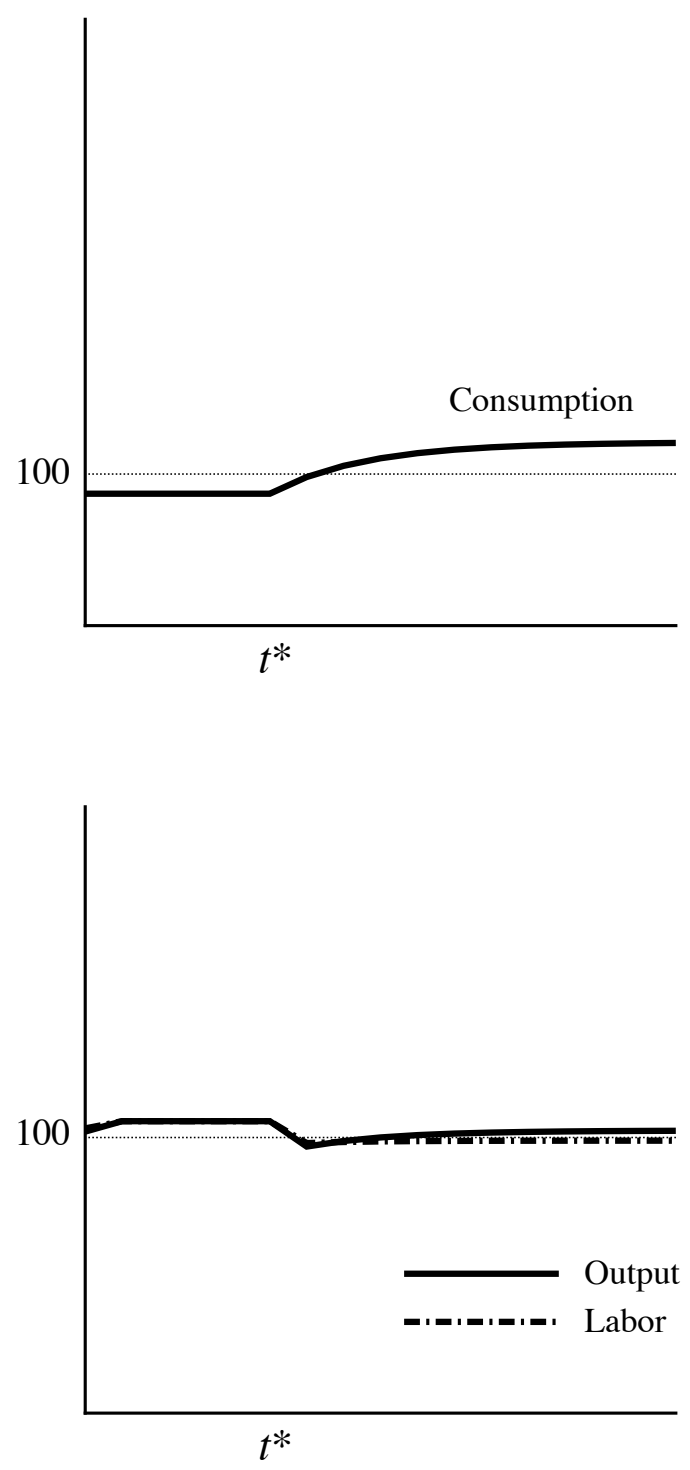
Figure 4. Detrended Capital Stocks, GDP, and GNP over Time in the Two-Country Model without Portfolio Restrictions (initial steady state $=100$ )

A. Small Country
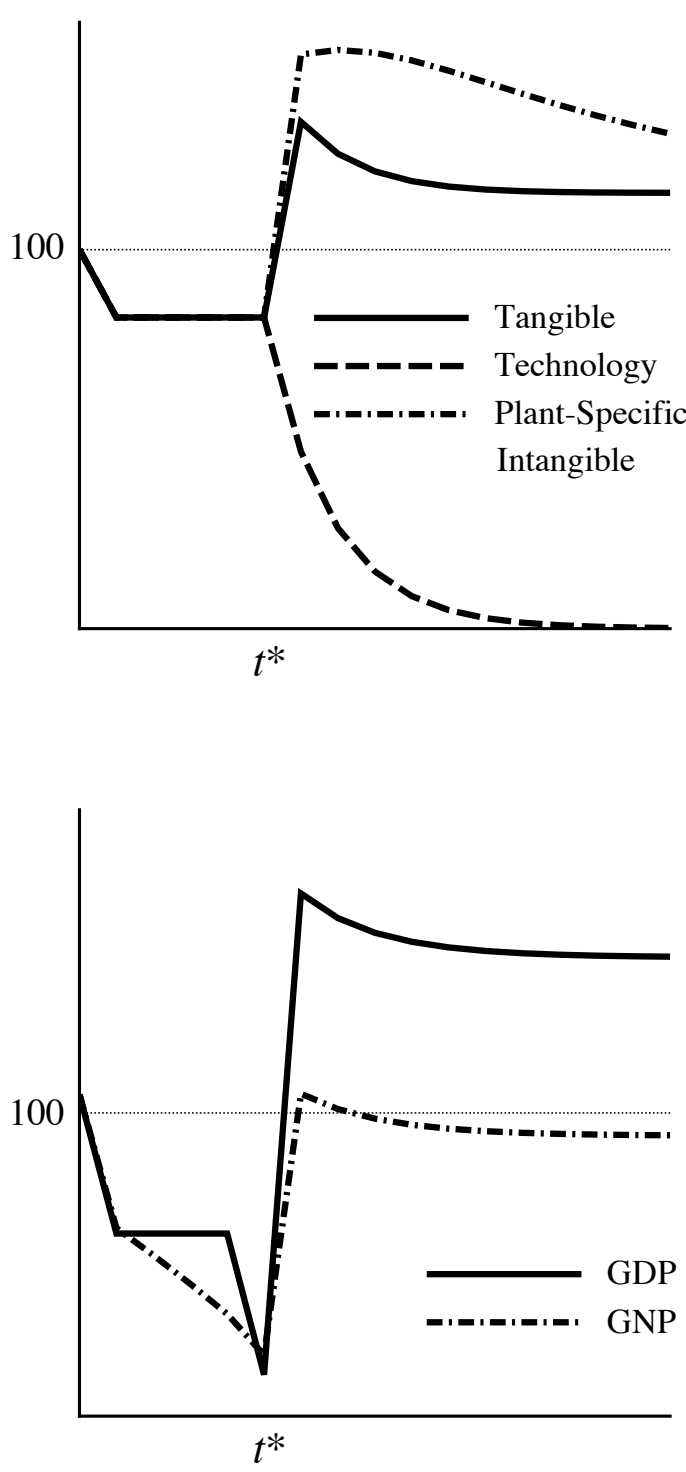

B. Large Country
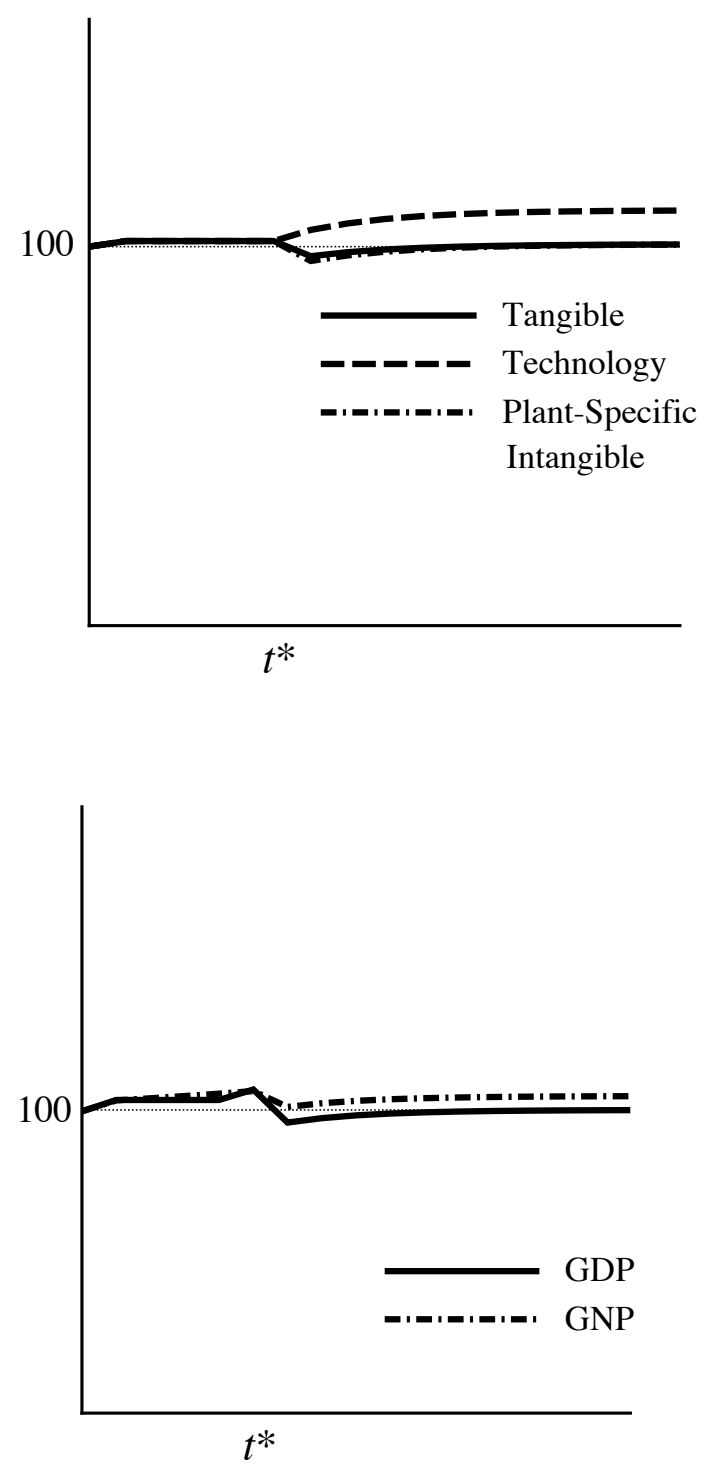
Figure 5. A Comparison of Detrended Consumption and GDP with and without Portfolio Restrictions in the Two-Country Model (initial steady state $=100$ )

A. Small Country
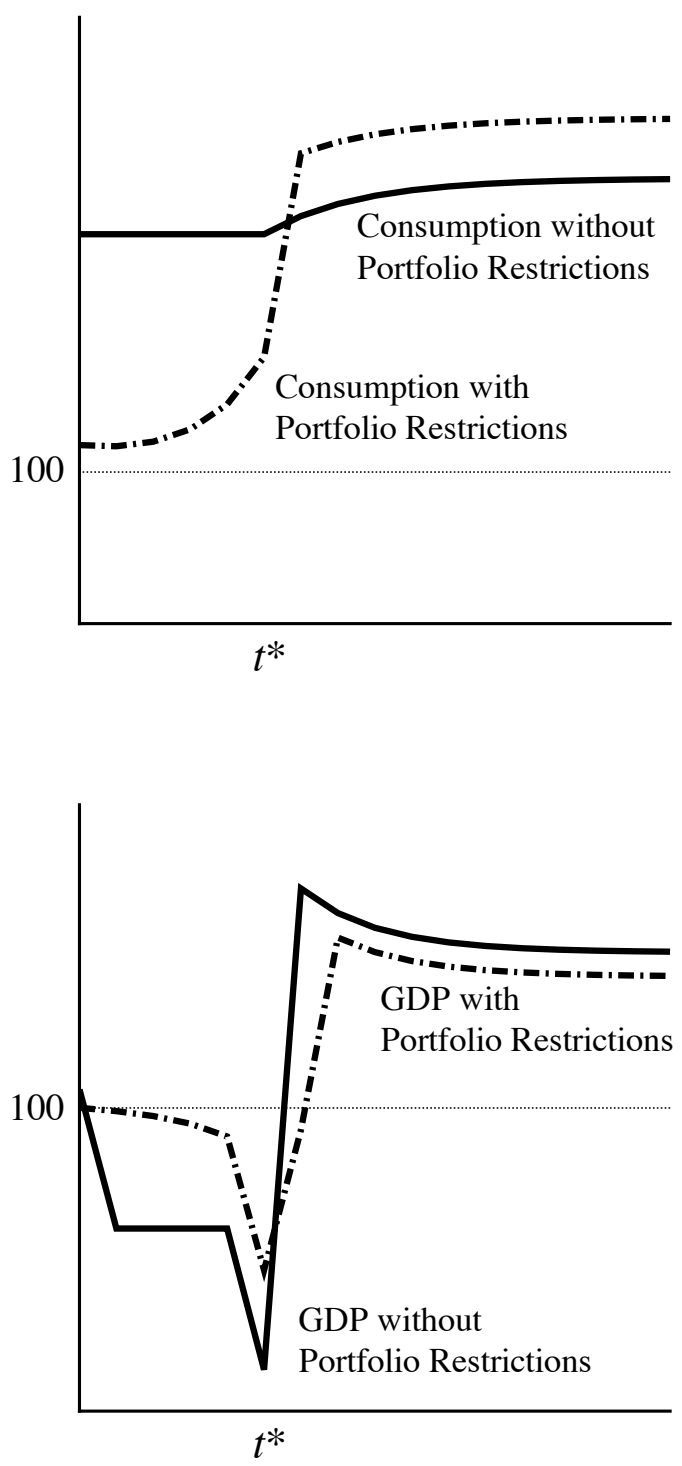

B. Large Country
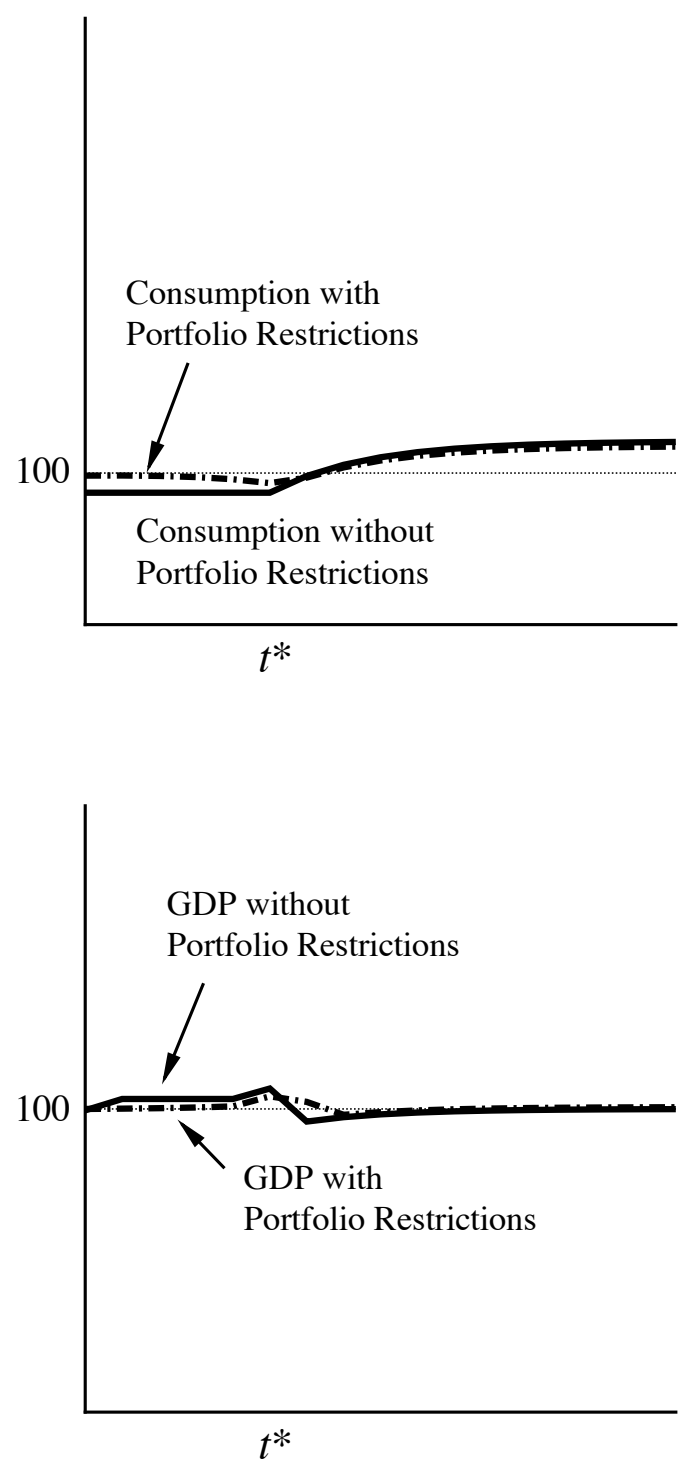
Figure 6. Predicted vs. Actual Share of Each Country's

Total Employment Controlled by Foreign Firms

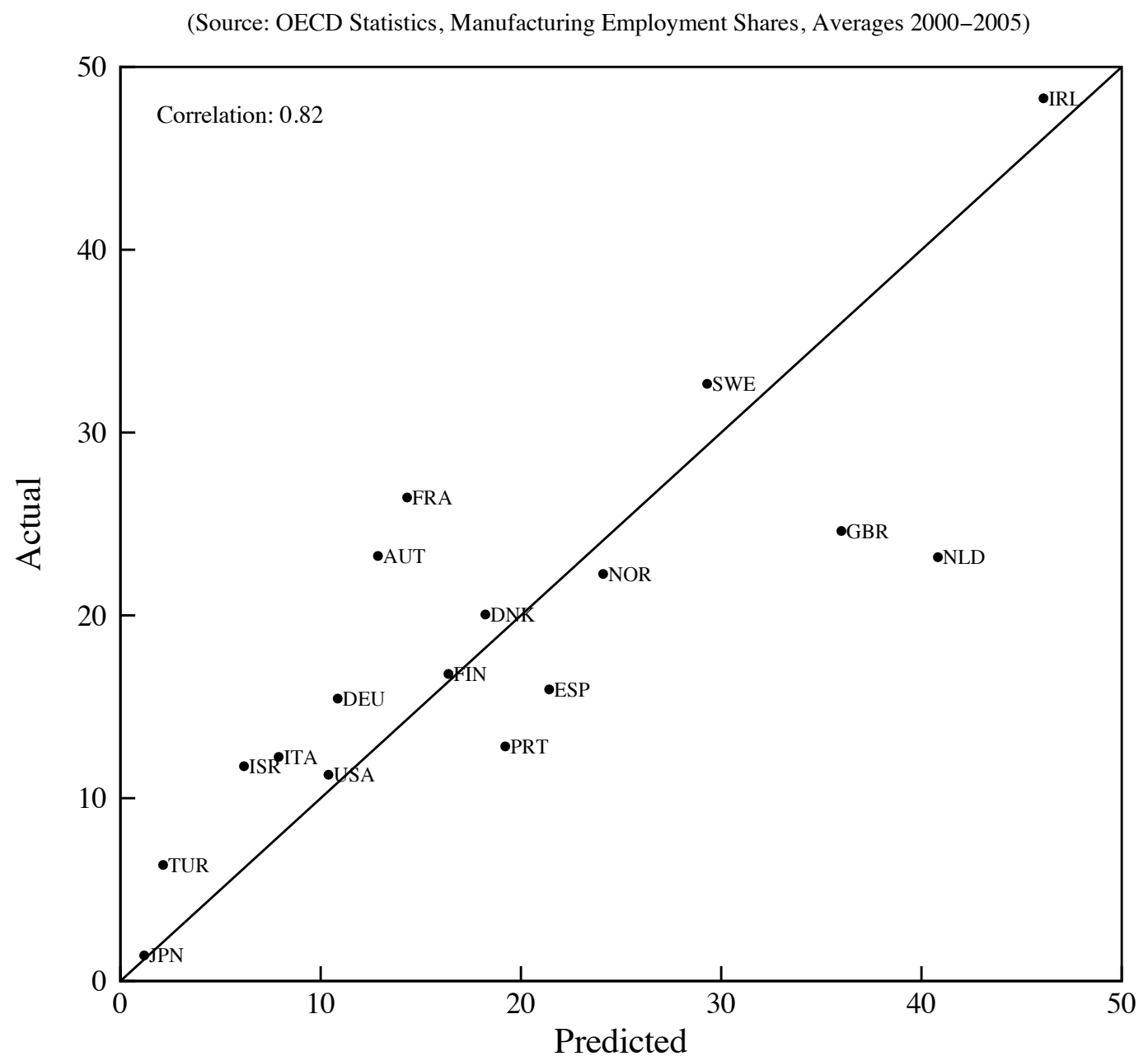


Figure 7. Predicted vs. Actual Share of Total U.S. Employment in Foreign Controlled Establishments by Country

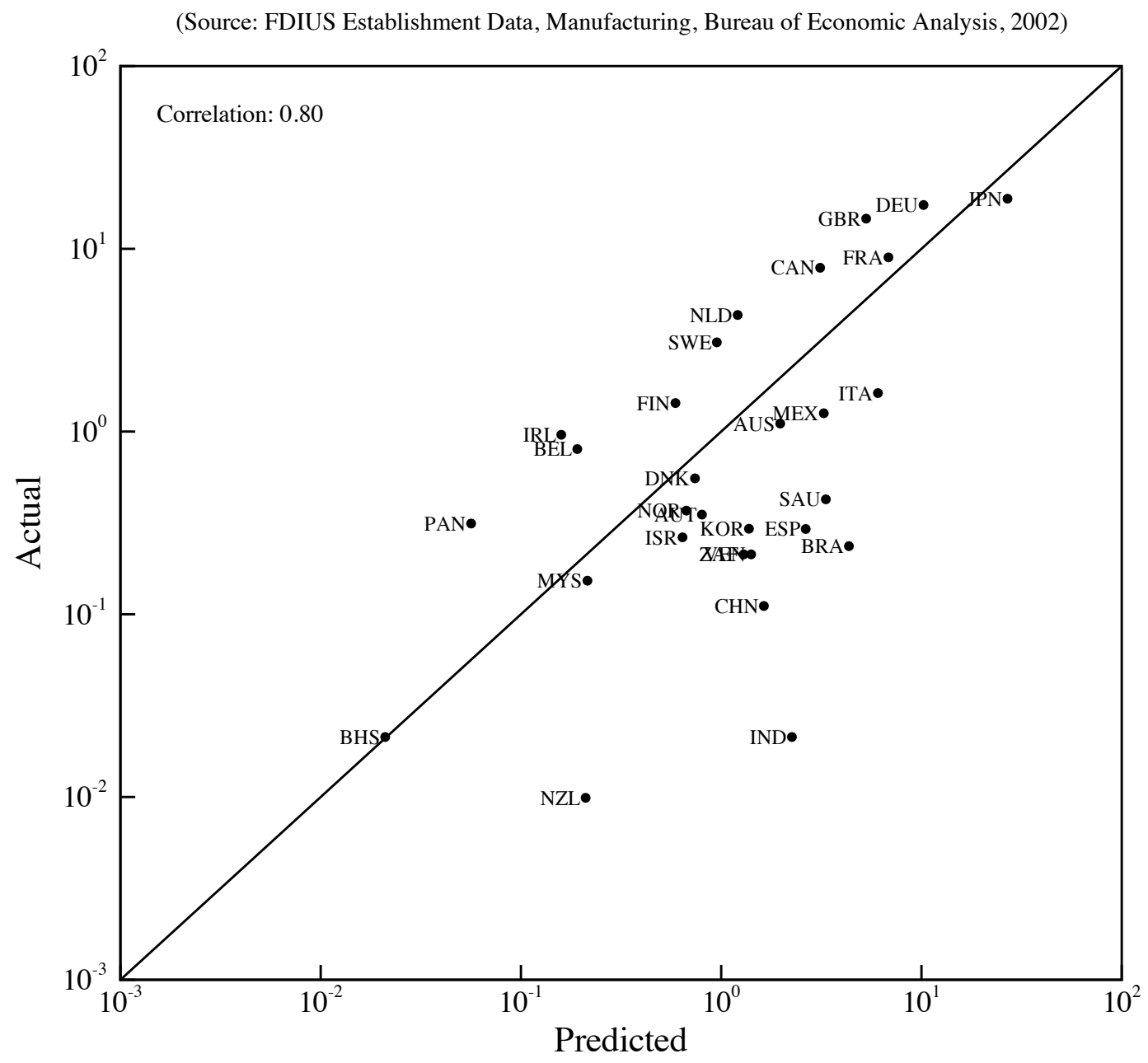


Figure 8. Predicted vs. Actual Share of Each Country's Total Employment Controlled by U.S. Firms

(Source: USDIA Benchmark Data, Manufacturing, Bureau of Economic Analysis, 2004)

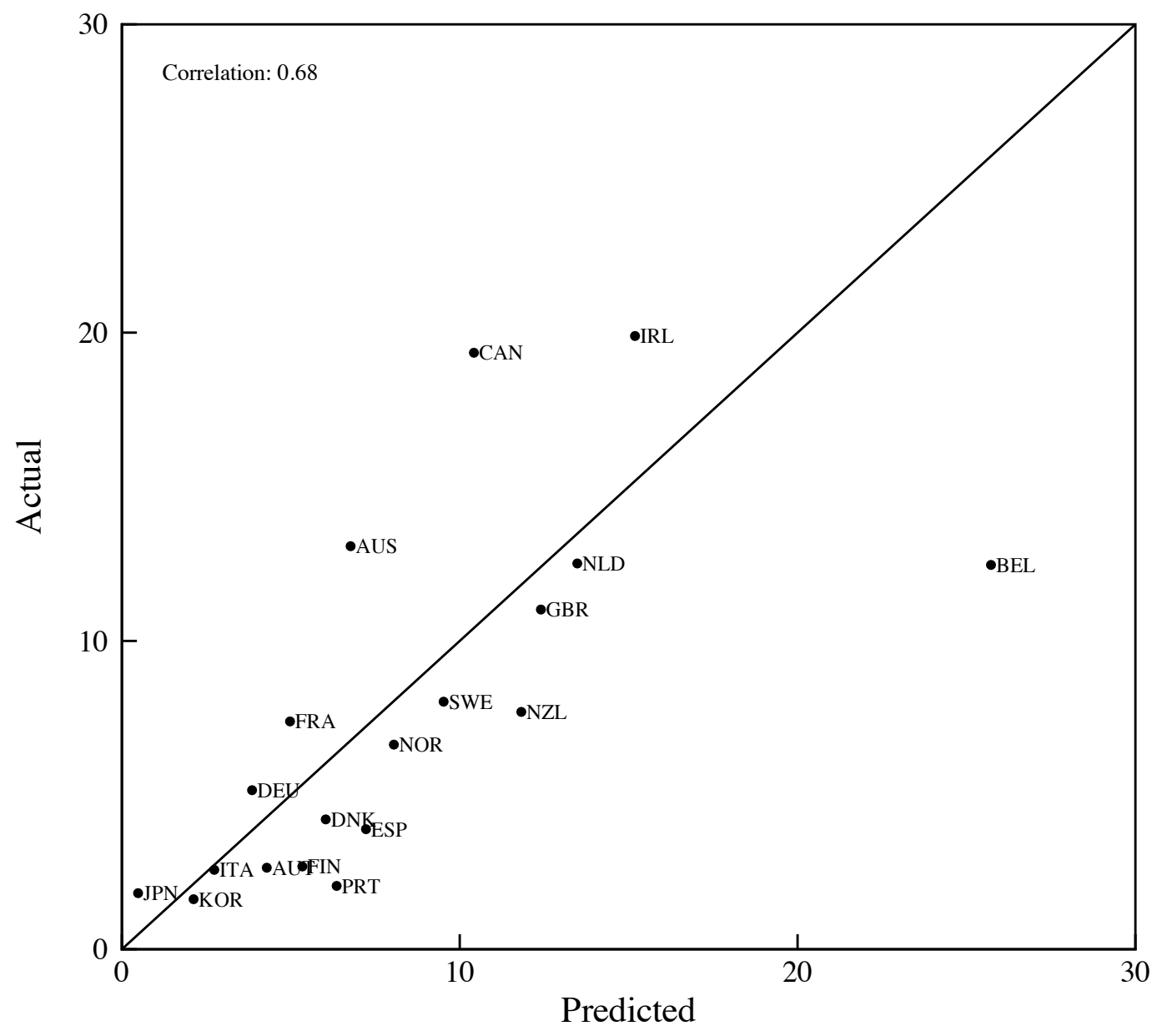


Figure 9. 1980 Real GDP and Predicted Growth Rates, 104 Countries (Countries with average FDI/GDP $>1.8 \%$ labeled)

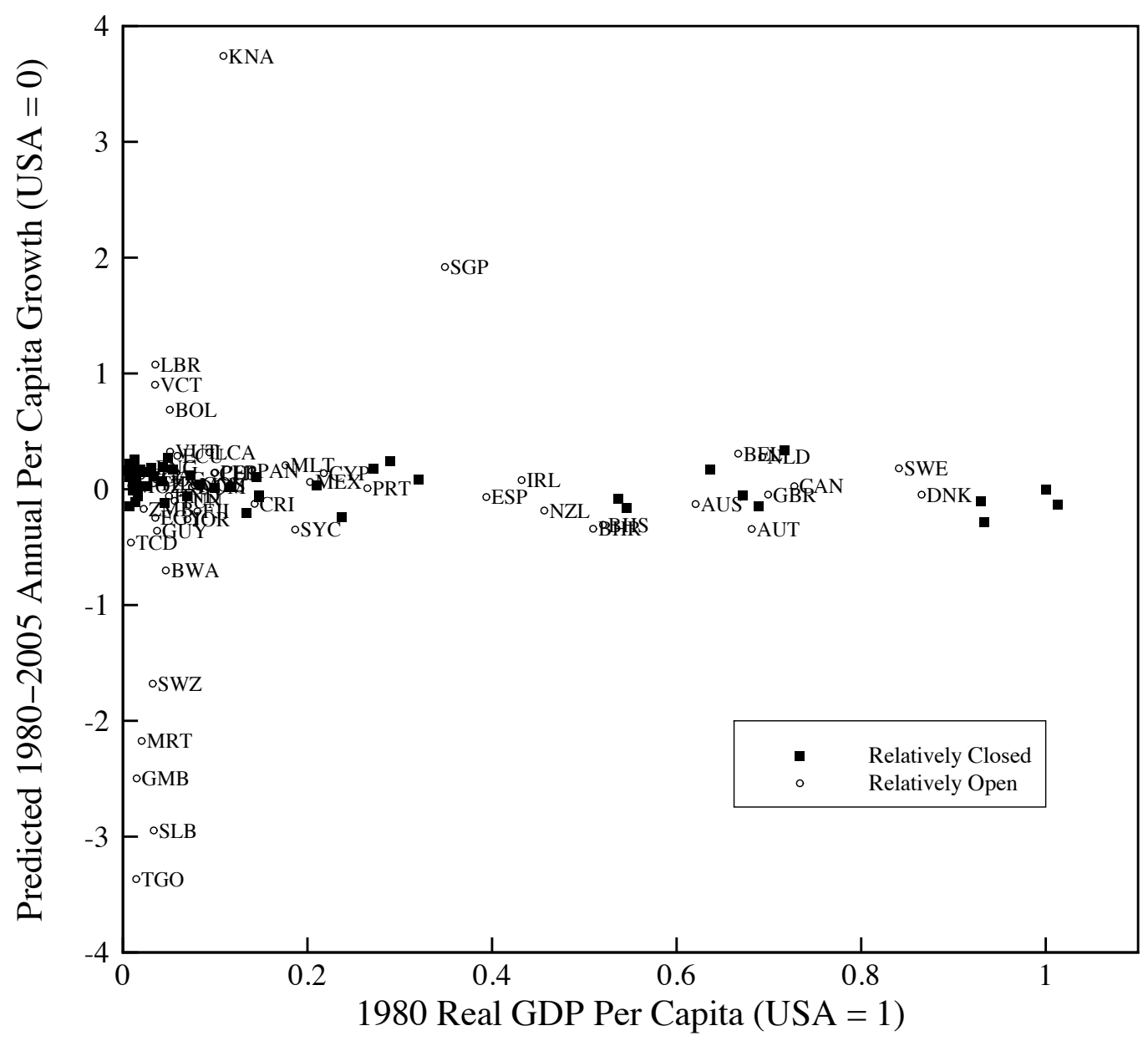


Figure 10. Predicted Change in Relative Growth of Unilaterally Opening to FDI and Portfolio Investment, by Country

(Degree of openness increased to 0.95 after 1980 and portfolio restrictions removed)

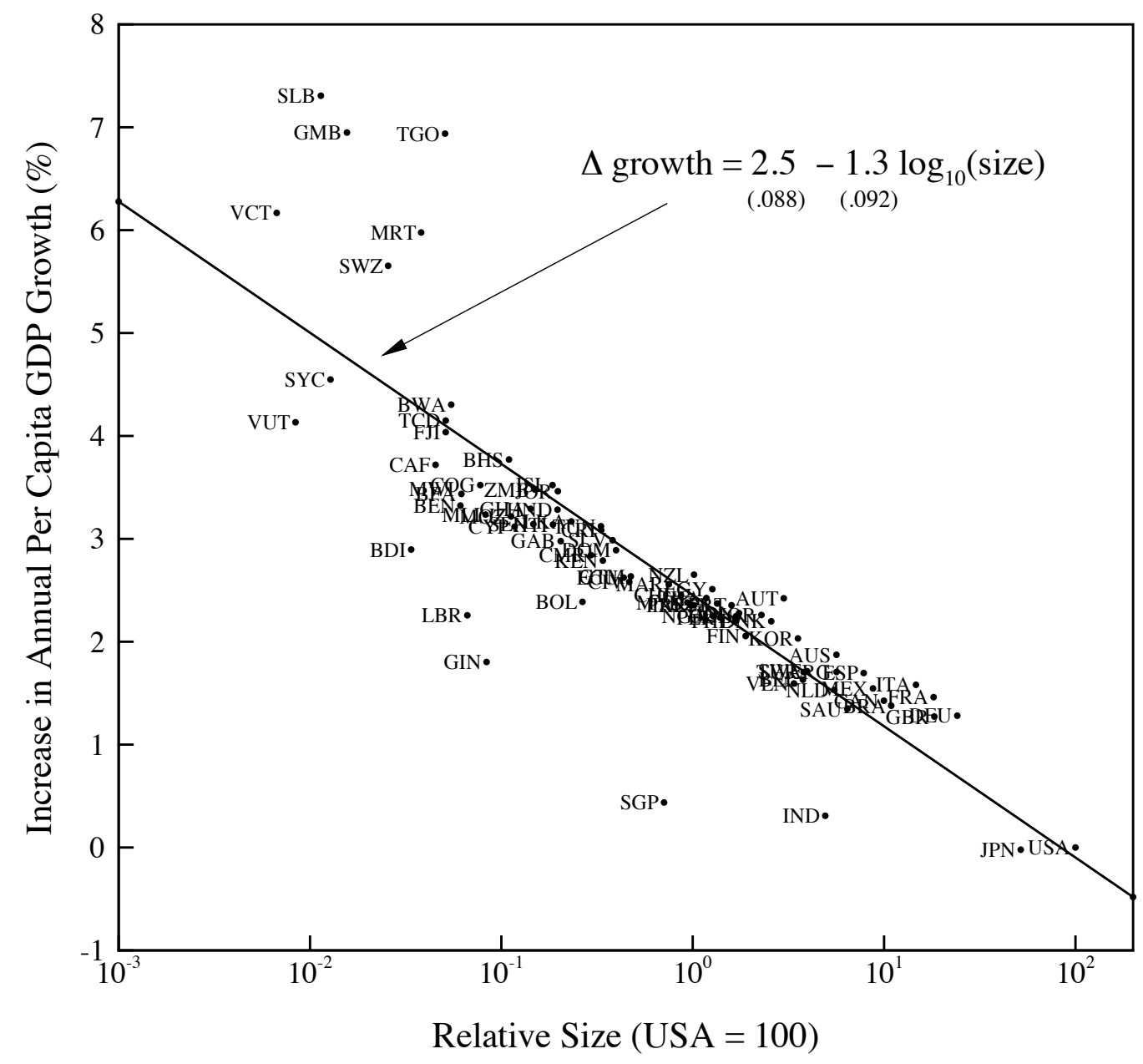


Figure 11. Predicted Welfare Gains of Unilaterally Opening to FDI and Portfolio Investment, by Country

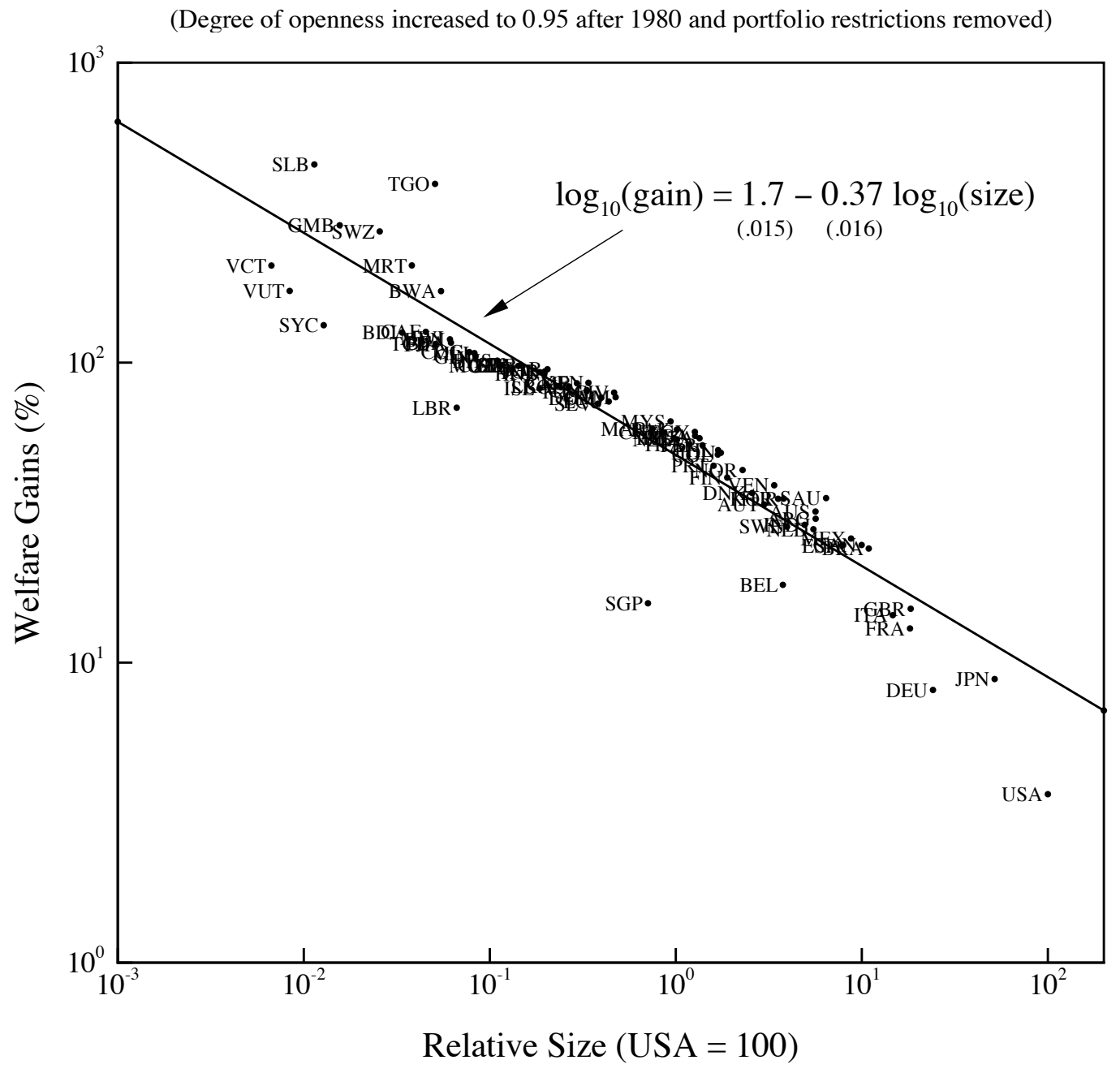


Table 1. TFP and Population Inputs, 104-Country Model, USA $=100$

\begin{tabular}{|c|c|c|c|c|c|c|c|}
\hline & $A$ & $N_{1980}$ & $N_{1985}$ & $N_{1990}$ & $N_{1995}$ & $N_{2000}$ & $N_{2005}$ \\
\hline \multicolumn{8}{|l|}{ NORTh \& CENTRAL AMERICA } \\
\hline United States (USA) & 100 & 100 & 100 & 100 & 100 & 100 & 100 \\
\hline Canada (CAN) & 93.5 & 10.8 & 10.9 & 11.1 & 11.0 & 10.9 & 10.9 \\
\hline Costa Rica (CRI) & 38.4 & 1.0 & 1.1 & 1.2 & 1.3 & 1.4 & 1.5 \\
\hline Dominican Republic (DOM) & 23.7 & 2.5 & 2.8 & 2.9 & 3.0 & 3.1 & 3.2 \\
\hline El Salvador (SLV) & 29.3 & 2.0 & 2.1 & 2.1 & 2.2 & 2.1 & 2.0 \\
\hline Guatemala (GTM) & 22.9 & 3.0 & 3.3 & 3.6 & 3.8 & 4.0 & 4.3 \\
\hline Honduras (HND) & 18.9 & 1.5 & 1.8 & 2.0 & 2.1 & 2.2 & 2.3 \\
\hline Mexico (MEX) & 38.4 & 28.8 & 31.7 & 33.3 & 34.2 & 34.7 & 34.9 \\
\hline Panama (PAN) & 38.7 & 0.8 & 0.9 & 1.0 & 1.0 & 1.0 & 1.1 \\
\hline \multicolumn{8}{|l|}{ EUROPE } \\
\hline Austria (AUT) & 98.7 & 3.4 & 3.2 & 3.1 & 3.0 & 2.8 & 2.8 \\
\hline Belgium-Luxembourg (BEL) & 94.4 & 4.6 & 4.3 & 4.1 & 4.0 & 3.8 & 3.7 \\
\hline Cyprus (CYP) & 54.0 & 0.3 & 0.3 & 0.3 & 0.3 & 0.3 & 0.3 \\
\hline Denmark (DNK) & 119 & 2.3 & 2.1 & 2.1 & 2.0 & 1.9 & 1.8 \\
\hline Finland (FIN) & 97.7 & 2.1 & 2.1 & 2.0 & 1.9 & 1.8 & 1.8 \\
\hline France (FRA) & 86.5 & 24.0 & 23.2 & 22.7 & 21.7 & 20.9 & 20.6 \\
\hline Germany (DEU) & 83.1 & 35.1 & 32.7 & 31.8 & 30.7 & 29.1 & 27.9 \\
\hline Iceland (ISL) & 155 & 0.1 & 0.1 & 0.1 & 0.1 & 0.1 & 0.1 \\
\hline Ireland (IRL) & 76.5 & 1.5 & 1.5 & 1.4 & 1.4 & 1.3 & 1.4 \\
\hline Italy (ITA) & 74.2 & 25.2 & 23.8 & 22.7 & 21.3 & 20.2 & 19.8 \\
\hline Malta (MLT) & 49.5 & 0.2 & 0.1 & 0.1 & 0.1 & 0.1 & 0.1 \\
\hline Netherlands (NLD) & 95.1 & 6.3 & 6.1 & 6.0 & 5.8 & 5.6 & 5.5 \\
\hline Norway (NOR) & 125 & 1.8 & 1.7 & 1.7 & 1.6 & 1.6 & 1.6 \\
\hline Portugal (PRT) & 52.5 & 4.3 & 4.2 & 4.0 & 3.8 & 3.6 & 3.6 \\
\hline Sweden (SWE) & 113 & 3.7 & 3.5 & 3.4 & 3.3 & 3.1 & 3.1 \\
\hline Spain (ESP) & 61.6 & 16.5 & 16.1 & 15.6 & 14.8 & 14.3 & 14.7 \\
\hline Turkey (TUR) & 27.8 & 19.8 & 21.6 & 22.5 & 23.0 & 23.6 & 24.1 \\
\hline United Kingdom (GBR) & 86.2 & 25.3 & 23.8 & 22.9 & 21.8 & 20.9 & 20.4 \\
\hline \multicolumn{8}{|l|}{ ASIA } \\
\hline China $(\mathrm{CHN})$ & 3.7 & 429.5 & 442 & 455 & 453 & 448 & 441 \\
\hline Korea (KOR) & 32.6 & 16.6 & 17.2 & 17.2 & 16.9 & 16.7 & 16.3 \\
\hline India (IND) & 4.7 & 295 & 322 & 340 & 350 & 360 & 370 \\
\hline Indonesia (IDN) & 6.9 & 63.9 & 68.5 & 71.4 & 72.4 & 73.1 & 74.6 \\
\hline Japan (JPN) & 106 & 51.6 & 50.8 & 49.5 & 47.1 & 45.0 & 43.2 \\
\hline Malaysia (MYS) & 22.5 & 5.9 & 6.6 & 7.3 & 7.7 & 8.2 & 8.7 \\
\hline Pakistan (PAK) & 6.6 & 35.0 & 39.8 & 43.3 & 46.0 & 48.9 & 52.7 \\
\hline Philippines (PHL) & 14.2 & 20.5 & 23.1 & 25.0 & 26.3 & 27.5 & 28.9 \\
\hline Singapore (SGP) & 65.6 & 1.1 & 1.1 & 1.2 & 1.3 & 1.4 & 1.4 \\
\hline Sri Lanka (LKA) & 8.9 & 6.5 & 6.7 & 6.9 & 6.8 & 6.6 & 6.7 \\
\hline Thailand (THA) & 12.1 & 20.3 & 22.1 & 22.7 & 22.6 & 22.1 & 22.3 \\
\hline Vanuatu (VUT) & 23.8 & 0.0 & 0.1 & 0.1 & 0.1 & 0.1 & 0.1 \\
\hline \multicolumn{8}{|l|}{ MIDDLE EAST } \\
\hline Bahrain (BHR) & 102 & 0.1 & 0.2 & 0.2 & 0.2 & 0.2 & 0.2 \\
\hline Oman (OMN) & 51.4 & 0.5 & 0.6 & 0.7 & 0.8 & 0.9 & 0.9 \\
\hline Egypt (EGY) & 12.3 & 19.0 & 21.3 & 23.1 & 24.0 & 24.9 & 26.1 \\
\hline Israel (ISR) & 88.8 & 1.7 & 1.8 & 1.9 & 2.1 & 2.2 & 2.3 \\
\hline Jordan (JOR) & 24.4 & 0.9 & 1.1 & 1.3 & 1.6 & 1.7 & 1.8 \\
\hline Saudi Arabia (SAU) & 101 & 3.8 & 5.4 & 6.6 & 7.0 & 7.3 & 7.8 \\
\hline Syria (SYR) & 16.3 & 3.8 & 4.5 & 5.1 & 5.5 & 5.9 & 6.5 \\
\hline \multicolumn{8}{|l|}{ OCEANIA } \\
\hline Australia (AUS) & 88.0 & 6.4 & 6.6 & 6.8 & 6.8 & 6.8 & 6.9 \\
\hline Fiji (FJI) & 29.0 & 0.3 & 0.3 & 0.3 & 0.3 & 0.3 & 0.3 \\
\hline New Zealand (NZL) & 80.0 & 1.4 & 1.4 & 1.4 & 1.4 & 1.4 & 1.4 \\
\hline Papua N. Guinea (PNG) & 13.6 & 1.4 & 1.5 & 1.7 & 1.8 & 1.9 & 2.1 \\
\hline Solomon Is. (SLB) & 17.3 & 0.1 & 0.1 & 0.1 & 0.1 & 0.1 & 0.2 \\
\hline
\end{tabular}


Table 1. TFP and Population Inputs, 104-Country Model, USA $=100$ (cont.)

\begin{tabular}{|c|c|c|c|c|c|c|c|}
\hline & $A$ & $N_{1980}$ & $N_{1985}$ & $N_{1990}$ & $N_{1995}$ & $N_{2000}$ & $N_{2005}$ \\
\hline \multicolumn{8}{|c|}{ SOUTH AMERICA \& CARIBBEAN } \\
\hline Argentina (ARG) & 55.2 & 12.2 & 12.7 & 13.1 & 13.1 & 13.1 & 13.1 \\
\hline Bahamas (BHS) & 105 & 0.1 & 0.1 & 0.1 & 0.1 & 0.1 & 0.1 \\
\hline Bolivia (BOL) & 18.7 & 2.3 & 2.5 & 2.7 & 2.8 & 2.9 & 3.1 \\
\hline Brazil (BRA) & 29.5 & 52.1 & 57.2 & 59.9 & 60.7 & 61.7 & 63.0 \\
\hline Chile (CHL) & 27.3 & 4.9 & 5.1 & 5.3 & 5.4 & 5.5 & 5.5 \\
\hline Colombia (COL) & 22.5 & 11.7 & 12.6 & 13.3 & 13.7 & 14.1 & 14.5 \\
\hline Ecuador (ECU) & 20.0 & 3.4 & 3.8 & 4.1 & 4.3 & 4.4 & 4.4 \\
\hline Guyana (GUY) & 17.4 & 0.3 & 0.3 & 0.3 & 0.3 & 0.3 & 0.3 \\
\hline Haiti (HTI) & 14.0 & 2.5 & 2.7 & 2.8 & 2.9 & 3.0 & 3.1 \\
\hline Jamaica (JAM) & 37.6 & 0.9 & 1.0 & 1.0 & 0.9 & 0.9 & 0.9 \\
\hline Paraguay (PRY) & 20.2 & 1.3 & 1.5 & 1.7 & 1.8 & 1.9 & 2.0 \\
\hline Peru (PER) & 26.8 & 7.4 & 8.2 & 8.7 & 9.0 & 9.2 & 9.4 \\
\hline St. Kitts (KNA) & 43.4 & 0.0 & 0.0 & 0.0 & 0.0 & 0.0 & 0.0 \\
\hline St. Lucia (LCA) & 34.8 & 0.1 & 0.1 & 0.1 & 0.1 & 0.1 & 0.1 \\
\hline St. Vincent (VCT) & 27.1 & 0.0 & 0.0 & 0.0 & 0.0 & 0.0 & 0.0 \\
\hline Uruguay (URY) & 52.1 & 1.3 & 1.3 & 1.2 & 1.2 & 1.2 & 1.1 \\
\hline Venezuela (VEN) & 54.1 & 6.4 & 7.3 & 7.9 & 8.3 & 8.6 & 9.0 \\
\hline \multicolumn{8}{|l|}{ AFRICA } \\
\hline Algeria (DZA) & 23.5 & 7.9 & 9.3 & 10.1 & 10.6 & 10.8 & 11.1 \\
\hline Benin (BEN) & 7.9 & 1.5 & 1.7 & 1.9 & 2.1 & 2.4 & 2.7 \\
\hline Botswana (BWA) & 19.0 & 0.4 & 0.5 & 0.5 & 0.6 & 0.6 & 0.6 \\
\hline Burkina Faso (BFA) & 5.2 & 2.9 & 3.2 & 3.6 & 3.9 & 4.2 & 4.7 \\
\hline Burundi (BDI) & 4.9 & 1.8 & 2.1 & 2.3 & 2.3 & 2.3 & 2.5 \\
\hline Cameroon (CMR) & 12.9 & 3.8 & 4.4 & 4.9 & 5.3 & 5.6 & 6.0 \\
\hline Central Af. Rep. (CAF) & 9.2 & 1.0 & 1.1 & 1.2 & 1.3 & 1.4 & 1.4 \\
\hline Chad (TCD) & 5.9 & 2.0 & 2.2 & 2.4 & 2.7 & 3.0 & 3.4 \\
\hline Congo (COG) & 16.0 & 0.8 & 0.9 & 1.0 & 1.0 & 1.1 & 1.2 \\
\hline Cote d'Ivoire (CIV) & 17.6 & 3.4 & 4.4 & 5.1 & 5.6 & 6.1 & 6.5 \\
\hline Gabon (GAB) & 63.5 & 0.3 & 0.3 & 0.4 & 0.4 & 0.4 & 0.5 \\
\hline Gambia (GMB) & 9.9 & 0.3 & 0.3 & 0.4 & 0.4 & 0.5 & 0.5 \\
\hline Ghana (GHA) & 6.6 & 4.7 & 5.5 & 6.0 & 6.5 & 6.9 & 7.4 \\
\hline Guinea (GIN) & 8.4 & 2.0 & 2.2 & 2.5 & 2.8 & 3.0 & 3.1 \\
\hline Kenya (KEN) & 9.0 & 6.8 & 8.3 & 9.4 & 10.3 & 11.1 & 12.0 \\
\hline Liberia (LBR) & 15.1 & 0.8 & 0.9 & 0.9 & 0.7 & 1.0 & 1.1 \\
\hline Madagascar (MDG) & 8.6 & 3.7 & 4.1 & 4.5 & 4.9 & 5.4 & 6.0 \\
\hline Malawi (MWI) & 5.2 & 2.6 & 3.1 & 3.8 & 3.8 & 4.1 & 4.5 \\
\hline Mali (MLI) & 7.1 & 2.6 & 2.9 & 3.1 & 3.3 & 3.5 & 3.9 \\
\hline Mauritania (MRT) & 11.0 & 0.6 & 0.7 & 0.8 & 0.8 & 0.9 & 1.0 \\
\hline Mauritius (MUS) & 25.9 & 0.4 & 0.4 & 0.4 & 0.4 & 0.4 & 0.4 \\
\hline Morocco (MAR) & 16.0 & 8.3 & 9.2 & 9.7 & 9.9 & 10.1 & 10.2 \\
\hline Mozambique (MOZ) & 5.7 & 5.2 & 5.6 & 5.4 & 6.0 & 6.4 & 6.9 \\
\hline Niger (NER) & 7.1 & 2.4 & 2.8 & 3.1 & 3.5 & 3.9 & 4.5 \\
\hline Nigeria (NGA) & 8.4 & 30.1 & 34.3 & 37.8 & 40.9 & 44.2 & 47.8 \\
\hline Rwanda (RWA) & 6.7 & 2.2 & 2.6 & 2.9 & 2.0 & 2.8 & 3.0 \\
\hline Senegal (SEN) & 11.0 & 2.4 & 2.7 & 3.0 & 3.3 & 3.5 & 3.8 \\
\hline Seychelles (SYC) & 56.6 & 0.0 & 0.0 & 0.0 & 0.0 & 0.0 & 0.0 \\
\hline Sierra Leone (SLE) & 7.6 & 1.4 & 1.5 & 1.6 & 1.5 & 1.5 & 1.7 \\
\hline South Africa (ZAF) & 33.5 & 11.8 & 13.2 & 14.1 & 14.7 & 15.6 & 15.9 \\
\hline Sudan $(\mathrm{SDN})$ & 7.2 & 8.6 & 10.1 & 10.9 & 11.6 & 12.4 & 13.1 \\
\hline Swaziland (SWZ) & 15.6 & 0.3 & 0.3 & 0.3 & 0.4 & 0.4 & 0.4 \\
\hline Togo (TGO) & 8.2 & 1.2 & 1.4 & 1.6 & 1.7 & 1.9 & 2.0 \\
\hline Tunisia (TUN) & 19.5 & 2.7 & 3.1 & 3.3 & 3.4 & 3.4 & 3.4 \\
\hline Zambia (ZMB) & 10.9 & 2.4 & 2.9 & 3.2 & 3.4 & 3.7 & 4.0 \\
\hline Zimbabwe (ZWE) & 11.6 & 3.1 & 3.7 & 4.2 & 4.4 & 4.4 & 4.2 \\
\hline
\end{tabular}


Table 2. Degree of Openness $\sigma$ and Periods Portfolio is Constrained $T_{c}, 104$-Country Model

\begin{tabular}{|c|c|c|c|c|c|c|c|c|c|}
\hline & $\sigma_{1980}$ & $\sigma_{1985}$ & $\sigma_{1990}$ & $\sigma_{1995}$ & $\sigma_{2000}$ & $\sigma_{2005}$ & $\sigma_{2010}$ & $\sigma_{2015}$ & $T_{c}$ \\
\hline \multicolumn{10}{|l|}{ NORTh \& CENTRAL AMERICA } \\
\hline United States (USA) & 0.76 & 0.76 & 0.76 & 0.76 & 0.76 & 0.86 & 0.86 & 0.86 & 0 \\
\hline Canada (CAN) & 0.72 & 0.69 & 0.69 & 0.69 & 0.69 & 0.75 & 0.75 & 0.75 & 0 \\
\hline Costa Rica (CRI) & 0.53 & 0.53 & 0.53 & 0.53 & 0.53 & 0.53 & 0.59 & 0.59 & 6 \\
\hline Dominican Republic (DOM) & 0.53 & 0.51 & 0.51 & 0.51 & 0.51 & 0.58 & 0.58 & 0.58 & 3 \\
\hline El Salvador (SLV) & 0.49 & 0.49 & 0.49 & 0.49 & 0.49 & 0.56 & 0.56 & 0.56 & 4 \\
\hline Guatemala (GTM) & 0.56 & 0.56 & 0.56 & 0.56 & 0.56 & 0.56 & 0.56 & 0.56 & 6 \\
\hline Honduras (HND) & 0.49 & 0.49 & 0.49 & 0.49 & 0.49 & 0.49 & 0.56 & 0.56 & 7 \\
\hline Mexico (MEX) & 0.65 & 0.65 & 0.65 & 0.65 & 0.69 & 0.73 & 0.73 & 0.73 & 3 \\
\hline Panama (PAN) & 0.50 & 0.50 & 0.50 & 0.50 & 0.54 & 0.58 & 0.58 & 0.58 & 1 \\
\hline \multicolumn{10}{|l|}{ EUROPE } \\
\hline Austria (AUT) & 0.57 & 0.57 & 0.57 & 0.57 & 0.57 & 0.57 & 0.71 & 0.71 & 0 \\
\hline Belgium-Luxembourg (BEL) & 0.65 & 0.65 & 0.65 & 0.65 & 0.65 & 0.82 & 0.82 & 0.82 & 4 \\
\hline Cyprus (CYP) & 0.54 & 0.54 & 0.54 & 0.54 & 0.54 & 0.57 & 0.57 & 0.57 & 4 \\
\hline Denmark (DNK) & 0.56 & 0.56 & 0.56 & 0.56 & 0.56 & 0.67 & 0.67 & 0.67 & 0 \\
\hline Finland (FIN) & 0.52 & 0.48 & 0.48 & 0.48 & 0.48 & 0.72 & 0.62 & 0.62 & 0 \\
\hline France (FRA) & 0.69 & 0.69 & 0.69 & 0.69 & 0.69 & 0.72 & 0.75 & 0.78 & 0 \\
\hline Germany (DEU) & 0.66 & 0.66 & 0.66 & 0.66 & 0.66 & 0.78 & 0.74 & 0.74 & 0 \\
\hline Iceland (ISL) & 0.45 & 0.40 & 0.40 & 0.40 & 0.40 & 0.40 & 0.50 & 0.58 & 0 \\
\hline Ireland (IRL) & 0.60 & 0.59 & 0.58 & 0.57 & 0.56 & 0.66 & 0.66 & 0.66 & 0 \\
\hline Italy (ITA) & 0.65 & 0.65 & 0.65 & 0.65 & 0.65 & 0.70 & 0.70 & 0.70 & 0 \\
\hline Malta (MLT) & 0.49 & 0.49 & 0.49 & 0.49 & 0.49 & 0.54 & 0.54 & 0.54 & 0 \\
\hline Netherlands (NLD) & 0.64 & 0.64 & 0.64 & 0.64 & 0.64 & 0.77 & 0.68 & 0.75 & 0 \\
\hline Norway (NOR) & 0.62 & 0.62 & 0.62 & 0.62 & 0.62 & 0.64 & 0.64 & 0.64 & 0 \\
\hline Portugal (PRT) & 0.55 & 0.55 & 0.55 & 0.55 & 0.55 & 0.65 & 0.63 & 0.63 & 0 \\
\hline Sweden (SWE) & 0.54 & 0.54 & 0.54 & 0.54 & 0.54 & 0.76 & 0.72 & 0.72 & 0 \\
\hline Spain (ESP) & 0.65 & 0.65 & 0.65 & 0.65 & 0.65 & 0.72 & 0.72 & 0.72 & 0 \\
\hline Turkey (TUR) & 0.52 & 0.52 & 0.52 & 0.52 & 0.52 & 0.52 & 0.65 & 0.65 & 7 \\
\hline United Kingdom (GBR) & 0.75 & 0.75 & 0.75 & 0.75 & 0.75 & 0.78 & 0.78 & 0.78 & 0 \\
\hline \multicolumn{10}{|l|}{ AsIA } \\
\hline China (CHN) & 0.34 & 0.73 & 0.73 & 0.73 & 0.73 & 0.73 & 0.73 & 0.73 & 4 \\
\hline Korea (KOR) & 0.55 & 0.55 & 0.55 & 0.55 & 0.55 & 0.63 & 0.63 & 0.63 & 1 \\
\hline India (IND) & 0.44 & 0.44 & 0.44 & 0.44 & 0.44 & 0.44 & 0.67 & 0.67 & 4 \\
\hline Indonesia (IDN) & 0.57 & 0.57 & 0.57 & 0.57 & 0.57 & 0.57 & 0.57 & 0.57 & 3 \\
\hline Japan (JPN) & 0.57 & 0.58 & 0.59 & 0.61 & 0.64 & 0.68 & 0.70 & 0.71 & 0 \\
\hline Malaysia (MYS) & 0.60 & 0.59 & 0.59 & 0.63 & 0.63 & 0.63 & 0.63 & 0.63 & 0 \\
\hline Pakistan (PAK) & 0.50 & 0.50 & 0.50 & 0.50 & 0.50 & 0.50 & 0.61 & 0.61 & 6 \\
\hline Philippines (PHL) & 0.56 & 0.56 & 0.56 & 0.56 & 0.56 & 0.57 & 0.59 & 0.61 & 3 \\
\hline Singapore (SGP) & 0.62 & 0.63 & 0.63 & 0.66 & 0.74 & 0.92 & 0.92 & 0.92 & 8 \\
\hline Sri Lanka (LKA) & 0.48 & 0.48 & 0.48 & 0.48 & 0.48 & 0.52 & 0.52 & 0.52 & 6 \\
\hline Thailand (THA) & 0.53 & 0.53 & 0.54 & 0.54 & 0.54 & 0.63 & 0.63 & 0.63 & 2 \\
\hline Vanuatu (VUT) & 0.43 & 0.39 & 0.39 & 0.39 & 0.47 & 0.47 & 0.47 & 0.47 & 7 \\
\hline \multicolumn{10}{|l|}{ MIDDLE EAST } \\
\hline Bahrain (BHR) & 0.26 & 0.66 & 0.66 & 0.66 & 0.66 & 0.66 & 0.66 & 0.66 & 0 \\
\hline Oman (OMN) & 0.54 & 0.52 & 0.52 & 0.52 & 0.52 & 0.52 & 0.56 & 0.56 & 4 \\
\hline Egypt (EGY) & 0.62 & 0.61 & 0.61 & 0.61 & 0.61 & 0.61 & 0.66 & 0.66 & 5 \\
\hline Israel (ISR) & 0.54 & 0.52 & 0.52 & 0.52 & 0.52 & 0.52 & 0.66 & 0.66 & 1 \\
\hline Jordan (JOR) & 0.49 & 0.47 & 0.47 & 0.47 & 0.47 & 0.47 & 0.60 & 0.60 & 6 \\
\hline Saudi Arabia (SAU) & 0.57 & 0.64 & 0.64 & 0.64 & 0.64 & 0.64 & 0.64 & 0.64 & 1 \\
\hline Syria (SYR) & 0.31 & 0.31 & 0.31 & 0.31 & 0.55 & 0.55 & 0.55 & 0.55 & 7 \\
\hline \multicolumn{10}{|l|}{ OCEANIA } \\
\hline Australia (AUS) & 0.66 & 0.66 & 0.66 & 0.66 & 0.66 & 0.66 & 0.70 & 0.70 & 0 \\
\hline Fiji (FJI) & 0.47 & 0.48 & 0.48 & 0.48 & 0.48 & 0.48 & 0.52 & 0.52 & 5 \\
\hline New Zealand (NZL) & 0.59 & 0.59 & 0.59 & 0.59 & 0.60 & 0.61 & 0.62 & 0.64 & 0 \\
\hline Papua N. Guinea (PNG) & 0.49 & 0.49 & 0.49 & 0.49 & 0.53 & 0.53 & 0.53 & 0.53 & 7 \\
\hline Solomon Is. (SLB) & 0.44 & 0.35 & 0.30 & 0.26 & 0.26 & 0.26 & 0.26 & 0.26 & 6 \\
\hline
\end{tabular}


Table 2. Degree of Openness $\sigma$ and Periods Portfolio is Constrained $T_{c}, 104$-Country Model (Cont.)

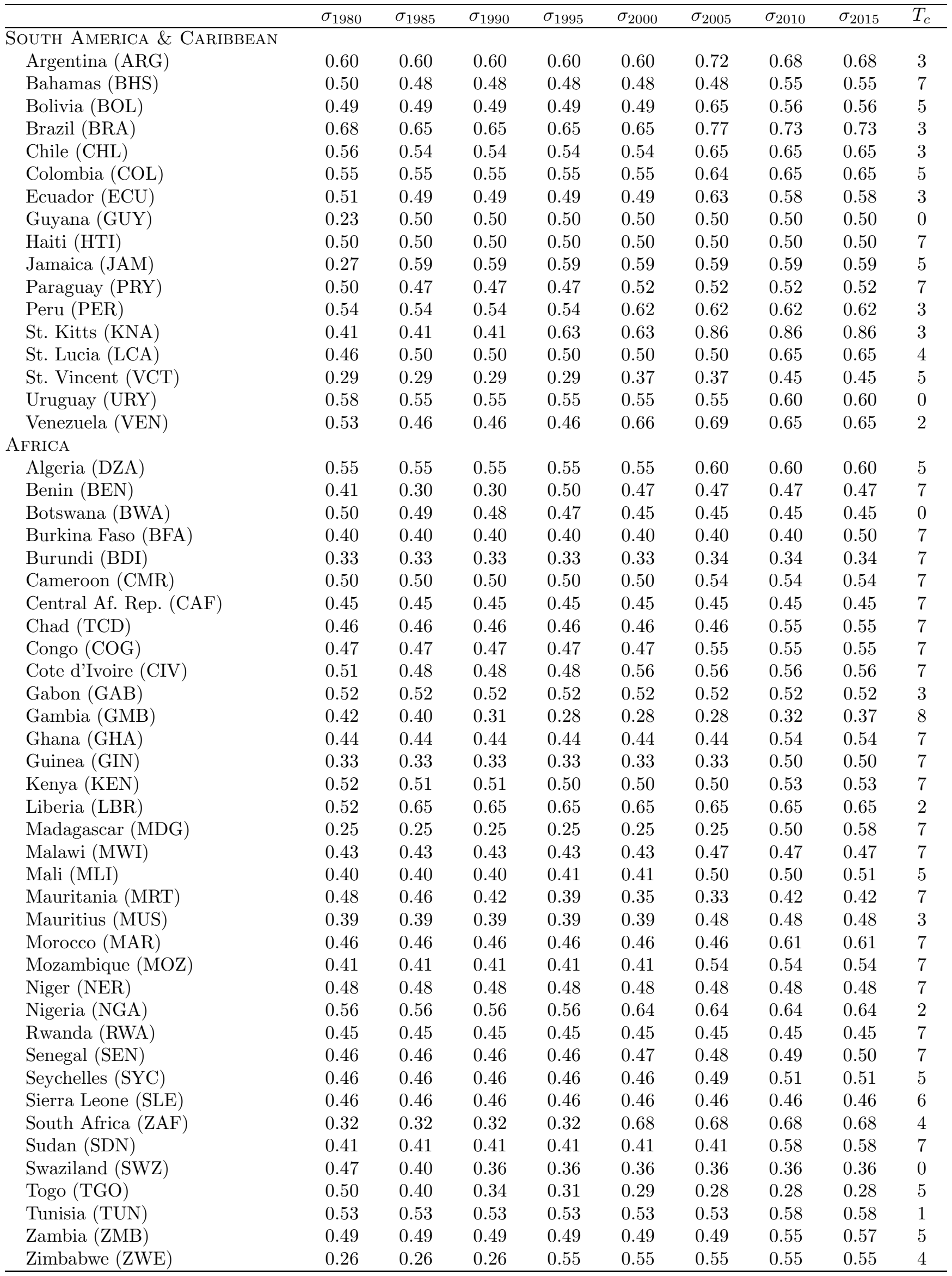


Table 3. Model Constants at Annual Rates

\begin{tabular}{|c|c|c|}
\hline PARAMETER & EXPRESSION & Value \\
\hline \multicolumn{3}{|l|}{ Preferences } \\
\hline Discount factor & $\beta$ & .98 \\
\hline Leisure weight & $\psi$ & 1.32 \\
\hline \multicolumn{3}{|l|}{ Growth Rates (\%) } \\
\hline Population & $\gamma_{N}$ & 1.0 \\
\hline Technology & $\gamma_{A}$ & 1.2 \\
\hline \multicolumn{3}{|l|}{ INCOME SHARES (\%) } \\
\hline Technology capital & $\phi$ & 7.0 \\
\hline Tangible capital & $(1-\phi) \alpha_{T}$ & 21.4 \\
\hline Plant-specific intangible capital & $(1-\phi) \alpha_{I}$ & 6.5 \\
\hline Labor & $(1-\phi)\left(1-\alpha_{T}-\alpha_{I}\right)$ & 65.1 \\
\hline \multicolumn{3}{|l|}{ DEPRECIATION RATES (\%) } \\
\hline Technology capital & $\delta_{M}$ & 8.0 \\
\hline Tangible capital & $\delta_{T}$ & 6.0 \\
\hline Plant-specific intangible capital & $\delta_{I}$ & 0 \\
\hline \multicolumn{3}{|l|}{ TAX RATES (\%) } \\
\hline Labor wedge & $\tau_{l i}$ & 34 \\
\hline Profits & $\tau_{p i}$ & 37 \\
\hline Dividends & $\tau_{d}$ & 28 \\
\hline
\end{tabular}

Note: See McGrattan and Prescott (2010) for details on these parameter choices. 
Table 4. Impact of FDI on Per Capita GDP Growth

Regression: $g=a_{0}+a_{1} g d p_{0}+a_{2} f d i / g d p$

$g=$ annual growth in real GDP per capita relative to U.S., 1980-2005 (U.S. $=0$ )

$g d p_{0}=$ real GDP per capita relative to U.S. in $1980($ U.S. $=1)$

$f d i / g d p=$ average ratio of FDI to GDP (in percentages), 1980-2005

\begin{tabular}{lrcc}
\hline & \multicolumn{3}{c}{ Coefficient } \\
\cline { 2 - 4 } & \multicolumn{1}{c}{$a_{0}$} & $a_{1}$ & $a_{2}$ \\
\hline \multirow{2}{*}{ Data } & -1.062 & 1.065 & 0.052 \\
& $(.288)$ & $(.660)$ & $(.063)$ \\
\multirow{2}{*}{ Model } & & 0.174 & 0.046 \\
& -0.209 & $(.264)$ & $(.026)$ \\
\hline
\end{tabular}

Note: Numbers in parentheses are standard errors. 